\title{
Diversity and Plant Growth Promoting Ability of Culturable Endophytic Bacteria in Nepalese Sweet Potato
}

\author{
Ramesh Raj Puri' ${ }^{1}$, Sangharash Raj Dangi ${ }^{2}$, \\ Sabitri Adhikari Dhungana ${ }^{1,2}$, Kazuhito Itoh ${ }^{1,3^{*}}$ \\ ${ }^{1}$ The United Graduate School of Agricultural Sciences, Tottori University, Tottori, Japan \\ ${ }^{2}$ Nepal Agricultural Research Council, Kathmandu, Nepal \\ ${ }^{3}$ Faculty of Life and Environmental Science, Shimane University, Shimane, Japan \\ Email: *itohkz@life.shimane-u.ac.jp
}

How to cite this paper: Puri, R.R., Dangi, S.R., Dhungana, S.A. and Itoh, K. (2018) Diversity and Plant Growth Promoting Ability of Culturable Endophytic Bacteria in Nepalese Sweet Potato. Advances in Microbiology, 8, 734-761.

https://doi.org/10.4236/aim.2018.89049

Received: August 27, 2018

Accepted: September 22, 2018

Published: September 25, 2018

Copyright $\odot 2018$ by authors and Scientific Research Publishing Inc. This work is licensed under the Creative Commons Attribution International License (CC BY 4.0).

http://creativecommons.org/licenses/by/4.0/

\section{Open Access}

\begin{abstract}
There is no information on Nepalese sweet potato endophytes. We isolated 243 endophytic bacteria belonging to 34 genera in six classes from 12 locations of Nepal. Among them, the predominant classes were Bacilli and Gammaproteobacteria. The principal component analysis revealed that the composition of bacterial classes was unrelated to the environmental parameters of the sampling sites. Regarding their plant growth promoting potentials, $57 \%$ of the strains demonstrated indole-3-acetic acid (IAA) producing ability while $5 \%$ strains had nitrogen fixing gene (nifH) and acetylene reduction assay (ARA) activity. The representative strains in all six classes showed antagonistic effect against bacterial pathogens while only Bacillus strain showed the effect against fungal pathogen. For endophytic traits, cellulase activity was observed in 5 classes, while pectinase activity was only in Proteobacteria. Fresh weight and vine length of sweet potato increased by inoculating mixed cultures of the isolates from each location.
\end{abstract}

\section{Keywords}

Sweet Potato, Endophytic Bacteria, IAA Production, Nitrogen Fixation, Antagonistic Effects

\section{Introduction}

Sweet potato (Ipomoea batatas L.) is a resilient, easily propagated crop which grows well in marginal lands. The plant can be cultivated in low-fertile soils, takes up more nitrogen than other root crops [1] [2]. The capacity of sweet po- 
tato to grow well in low fertile soils might be due to the endophytic bacteria with plant growth promoting traits. Endophytic diazotrophic bacteria such as Klebsiella, Pantoea and Gluconacetobacter have been isolated from sweet potatoes [3] [4] [5]. Similarly, sweet potato bacterial endophytes with auxin production, antagonistic effect, phosphate solubilization and siderophore production abilities have also been isolated [6] [7]. On the other hand, there have been a few studies on endophytic bacterial community from sweet potato crops. For instance, the community was examined for samples collected in Brazil [6] and in USA [7], and it was shown that Gammaproteobacteria was common dominating group in both studies.

Nepal, a small Himalayan country, lies along the southern slopes of the Himalayan Mountains between China and India. It varies greatly in topography, climate and vegetation; the elevation ranges from 68 to 8848 masl in a just 150 to $250-\mathrm{km}$ south-north transect. In Nepal, sweet potato is cultivated from terai (60 - 300 masl) to mid hills (300 - 2000 masl) and the average productivity is 5 - 6 tons $\mathrm{ha}^{-1}$ [8], while the world productivity is 12.2 tons ha $^{-1}$ [9]. Till date, there is no information on Nepalese sweet potato endophytes. Adhikari et al. reported that the diverse climate and soils in Nepal was suspected to be conducive for the occurrence of diverse soybean rhizobial strains [10]. So, we expect that diverse endophytic bacterial isolates with the potentials for plant growth promotion could be isolated from the Nepalese sweet potato.

Sustainability issues in agriculture are a priority for several countries in the world; in this regard, the use of microbial inoculants to the agriculture farming might contribute to ensure sustainable production. In this study, we aimed to examine bacterial community of sweet potato endophytes in Nepal in relation to the environmental parameters and characterize their plant growth promoting traits. As synergistic effect of mixed cultures of plant growth promoting bacteria was reported [11] [12], we also examined their potential by inoculating combined isolates from each location.

\section{Materials and Methods}

\subsection{Sample Collection and Study Sites}

Sweet potato tubers were collected from three months old plants during the autumn of 2015 representing 12 sweet potato growing sites in Nepal, six from subtropical and six from temperate regions. Sampling sites, climate and soil properties are presented in Table 1.

The sweet potato samples were washed with tap water, shade dried and kept at room temperature until the isolation of the endophytic bacteria. Soil samples collected from the same field during the spring of 2016 were air-dried and crushed to pass through a $2 \mathrm{~mm}$ sieve. The $\mathrm{pH}$ was measured using the glass electrode method with a soil: water ratio of 1:2.5 [13]. Total carbon (TC) and total nitrogen (TN) were determined by the dry combustion method using an NC analyzer (MT-700, J-Science, Kyoto, Japan). Available phosphorus (P) was 
Table 1. Climate, land and soil properties of the sweet potato sampling sites in Nepal.

\begin{tabular}{|c|c|c|c|c|c|c|c|c|c|c|c|c|}
\hline Climate & $\begin{array}{l}\text { Location } \\
\text { (District) }\end{array}$ & $\begin{array}{r}\text { Tem } \\
\mathrm{M}\end{array}$ & $\begin{array}{l}\text { ature }^{\mathrm{a}} \\
\text { Min }\end{array}$ & Latitude & Longitude & $\begin{array}{l}\text { Annual Rainfall } \\
(\mathrm{mm})^{\mathrm{a}}\end{array}$ & $\begin{array}{c}\text { Altitude } \\
\text { (masl) }\end{array}$ & Soil type ${ }^{\mathrm{b}}$ & Soil pH & Soil $\mathrm{P}^{c}$ & Soil $C^{c}$ & Soil N ${ }^{c}$ \\
\hline \multirow{6}{*}{$\begin{array}{l}\text { Temperate } \\
\text { (Cooler highland) }\end{array}$} & Rolpa & 32 & 3.4 & $28.30^{\circ} \mathrm{N}$ & $82.63^{\circ} \mathrm{E}$ & 1261 & 1200 & Inceptisols & 7.3 & 331 & 16 & 1.5 \\
\hline & Salyan & 31 & 6.5 & $28.42^{\circ} \mathrm{N}$ & $82.00^{\circ} \mathrm{E}$ & 987 & 1300 & Entisols & 6.2 & 4.8 & 11 & 0.8 \\
\hline & Gulmi & 28 & 4.3 & $28.02^{\circ} \mathrm{N}$ & $83.24^{\circ} \mathrm{E}$ & 1860 & 1500 & Entisols & 6.7 & 12 & 7.0 & 0.7 \\
\hline & Palpa & 33 & 6.1 & $27.89^{\circ} \mathrm{N}$ & $83.50^{\circ} \mathrm{E}$ & 1564 & 1219 & Entisols & 6.4 & 37 & 20 & 1.7 \\
\hline & Kavre-a & 28 & 2.8 & $27.62^{\circ} \mathrm{N}$ & $85.58^{\circ} \mathrm{E}$ & 1190 & 1408 & Entisols & 5.8 & 111 & 8.0 & 0.6 \\
\hline & Kavre-b & 28 & 2.8 & $27.61^{\circ} \mathrm{N}$ & $85.59^{\circ} \mathrm{E}$ & 1190 & 1116 & Entisols & 5.5 & 87 & 7.0 & 0.6 \\
\hline \multirow{6}{*}{$\begin{array}{l}\text { Subtropical } \\
\text { (warmer foothills } \\
\text { \& plains) }\end{array}$} & Banke-a & 39 & 8.0 & $28.02^{\circ} \mathrm{N}$ & $81.76^{\circ} \mathrm{E}$ & 1230 & 181 & Alfisols & 8.0 & 87 & 11 & 1.0 \\
\hline & Banke-b & 39 & 8.0 & $28.11^{\circ} \mathrm{N}$ & $81.59^{\circ} \mathrm{E}$ & 1230 & 179 & Alfisols & 8.4 & 6.2 & 8.0 & 0.7 \\
\hline & Rupandehi & 38 & 7.8 & $27.58^{\circ} \mathrm{N}$ & $83.31^{\circ} \mathrm{E}$ & 1572 & 107 & Alfisols & 8.3 & 11 & 4.0 & 0.3 \\
\hline & Chitwan & 36 & 6.2 & $27.65^{\circ} \mathrm{N}$ & $84.39^{\circ} \mathrm{E}$ & 1960 & 228 & Alfisols & 6.6 & 137 & 13 & 1.0 \\
\hline & Sunsari-a & 34 & 8.0 & $26.71^{\circ} \mathrm{N}$ & $87.25^{\circ} \mathrm{E}$ & 1816 & 107 & Alfisols & 6.7 & 379 & 20 & 1.7 \\
\hline & Sunsari-b & 34 & 8.0 & $26.70^{\circ} \mathrm{N}$ & $87.28^{\circ} \mathrm{E}$ & 1816 & 108 & Alfisols & 5.9 & 20 & 16 & 1.3 \\
\hline
\end{tabular}

${ }^{\mathrm{a}} 5$ years average of maximum, minimum annual temperature and annual rainfall (http://www.dhm.gov.np/); ${ }^{\mathrm{b} B a s e d}$ on USDA classification [26]; ${ }^{\mathrm{c} S o i l} \mathrm{P}$ in $\mathrm{mg} \mathrm{kg}{ }^{-1}$, and Soil $\mathrm{C}$ and Soil $\mathrm{N}$ in $\mathrm{g} \mathrm{kg}^{-1}$.

determined by Olsen's bicarbonate method [14].

\subsection{Isolation and Identification of Endophytic Bacteria}

The sweet potato samples were washed again with running tap water for $10 \mathrm{~min}$. Each sample was cut transversely when its diameter was more than $10 \mathrm{~mm}$ otherwise cut longitudinally. Then, the cut surface was stamped on the modified MR agar medium [4], and incubated for 2 days at $26^{\circ} \mathrm{C}$. The appeared colonies were grouped based on their morphologies and the representative colonies reflecting their relative abundance were purified for further analysis as endophytes.

The partial $16 \mathrm{~S}$ rRNA genes of the isolated endophytic bacteria were amplified using the universal primers (fD1 and rP2) to the domain bacteria [15]. The PCR mixture was prepared by mixing MilliQ water, 10x reaction buffer, $10 \mathrm{mM}$ dNTPs, Taq DNA polymerase (GENETBIO Inc., Daejeon, Korea), fD1 and rP2 primers together with the template. The PCR reaction was carried out with a pre-run at $94^{\circ} \mathrm{C}$ for $3 \mathrm{~min}, 30 \mathrm{~s}$ at $94^{\circ} \mathrm{C}, 30 \mathrm{~s}$ at $50^{\circ} \mathrm{C}, 1 \mathrm{~min}$ at $72^{\circ} \mathrm{C}$ for 30 cycles and final run at $72^{\circ} \mathrm{C}$ for $5 \mathrm{~min}$. The PCR products were sequenced as described by Adhikari et al. [10]. In brief, the respective PCR products were purified by using SOPE ${ }^{\mathrm{TM}}$ resin (Edge Biosystems Inc. USA) and a Performa Dye Terminator Removal (DTR) Gel Filtration Cartridge (Edge Biosystems Inc. USA). Then, their nucleotide sequences were analyzed by an ABI Prism, 3100-Avant-100D2 (3130 xl/Genetic Analyzer, Hitachi, Tokyo, Japan). Close relatives for each isolate was assigned using the data base (https://www.ddbj.nig.ac.jp/index-e.html) by a BLAST search [16]. 


\subsection{Distribution of Endophytic Bacteria in Relation to Environmental Conditions}

Correlation between bacterial class compositions and the environmental parameters (Table 1) of the sampling sites was analyzed by the principal component analysis (PCA). Bacterial class compositions as expressed by relative percentage were used for the calculation.

\subsection{Characterization of Endophytic Bacteria}

Sixty representative isolates of 34 genera in 6 classes were selected by their phylogenies (Table S1 \& Figure S1) and used for the characterization of their plant growth promoting traits, antagonistic effect and endophytic traits.

For indole-3-acetic acid (IAA) production assay, the isolates were cultivated in the modified MR liquid media supplemented with $200 \mu \mathrm{g} / \mathrm{ml}$ of L-tryptophan at $26^{\circ} \mathrm{C}$ for 3 days with shaking (150 rpm). After centrifugation at $8000 \mathrm{~g}$ for 15 min, the supernatant was applied for quantification of IAA according to the method described by Gordon and Weber [17].

For detection of nitrogen fixing gene (nifH), primers PolF and PolR which were designed to match a broad range of bacterial nifH gene [18] were used for PCR. The PCR components and conditions were as described by Adhikari et al. [10]. Nitrogenase activity of the nifH gene containing isolates was evaluated using the acetylene reduction assay (ARA). The isolates were cultivated in $\mathrm{N}$-free modified MR media [19] for 3 days at $26^{\circ} \mathrm{C}$ with shaking (150 rpm). Then, the culture was washed and suspended in sterile distilled water at $\mathrm{OD}_{660 \mathrm{~nm}} 0.2$. Then, $50 \mu \mathrm{l}$ of the suspension was inoculated on a slant of semi-solid (1.3\%) N-free modified MR agar media in $60 \mathrm{ml}$ vials in triplicate. The vials were sealed with a butyl-rubber and an aluminium stopper, and $10 \%$ of the headspace volume was replaced with pure acetylene. Vials without acetylene and without inoculants served as controls. Ethylene concentrations in the vials were measured after 3 days of incubation in dark at $28^{\circ} \mathrm{C}$, using a gas chromatograph (Shimadzu GC-14B; Shimadzu, Kyoto, Japan) equipped with a flame ionization detector and Porapak N (50/80 mesh; GL Sciences, Tokyo, Japan).

For assay of antagonistic effects, the point inoculation method [20] was used against the fungal pathogen (Pythium ultimum var ultimum Strain OPU744). Briefly, each test strain was streaked on the PDA plate (dextrose: $1 \mathrm{~g} \mathrm{l}^{-1}$, peptone: $5 \mathrm{~g} \mathrm{l}^{-1}$, yeast extract: $2.5 \mathrm{~g} \mathrm{l}^{-1}$ and agar: $15 \mathrm{~g} \mathrm{l}^{-1}$ ). After one day of cultivation at $28^{\circ} \mathrm{C}$, a $5 \mathrm{~mm}$ of fungal mycelial disk was placed at approximately $30 \mathrm{~mm}$ from the bacterial streaked line and continuously cultivated for 7 days. The corresponding fungal disk without endophyte strain served as control. To test antagonistic effect of endophytes against bacterial pathogens, each test isolates were streaked on a half part of PDA plates and incubated for 2 days at $28^{\circ} \mathrm{C}$. Then each bacterial pathogens (ECa: Erwinia chrysanthemi Strain NARCB200126, AZ9702, causing stem and root rot in sweet potato, ECb: Erwinia chrysanthemi Strain E7725, causing stem rot in potato and ECc: Erwinia chrysanthemi Strain 
Ech T5-2, causing root rot in Taro); was streaked approximately $5 \mathrm{~mm}$ to the endophytes and incubated at $28^{\circ} \mathrm{C}$ for 9 days. For both assays, antagonistic effects were categorized based on the distance between the test isolates and the pathogen as follows: no $(0 \mathrm{~mm})$, weak $(1-3 \mathrm{~mm})$ and strong $(>3 \mathrm{~mm})$ activities.

For the cellulase assay, the isolates were spotted on a carboxymethyl cellulose (CMC) agar medium [21]. Plates were incubated at $28^{\circ} \mathrm{C}$ for 6 days. The clear zone around the point of inoculation was examined by staining remaining CMC with Congo red [22]. For the pectinase assay, the test strains were spotted on a nutrient agar (DIFCO laboratories, USA) medium supplemented with $0.5 \%$ pectin and incubated at $28^{\circ} \mathrm{C}$ for 3 days, then remaining pectin was stained with cetyltrimethylammonium bromide (CTAB) to visualize the clear zone around the bacterial culture [23]. For both assays, the activities were categorized based on the clear zones around the bacterial colony as follows: no $(0 \mathrm{~mm})$, weak ( 1 - 3 $\mathrm{mm}$ ) and strong ( $>3 \mathrm{~mm})$ activities.

\subsection{Evaluation of Plant Growth Promotion in Sweet Potato with Endophytes}

The endophytes within the same location were selected for the inoculation experiment based on their phylogenies (Table S1). Each strain was cultivated separately in nitrogen containing modified MR liquid medium at $26^{\circ} \mathrm{C}$ with shaking for 5 days. The cells were harvested by centrifugation $(10,000 \mathrm{rpm}$ for $10 \mathrm{mi}$ nutes at $15^{\circ} \mathrm{C}$ ), washed twice and suspended with sterile distilled water, and $\mathrm{OD}_{660}$ was adjusted to 0.2 . Then, the cell suspensions of the same location were mixed together to make the inoculants in $10 \mathrm{ml}$ final volume. The experiment was conducted using a Leonard jar [24]. The upper pot was filled with water-soaked sterile vermiculite and the lower pot was supplied with $150 \mathrm{ml}$ of sterile $1 / 5 \mathrm{~N}$ plant medium [25]. The cotton wick was set to connect the upper pot and the lower reservoir. The whole pot was autoclaved before use.

Micro-propagated sweet potato plantlets cv. Koukei (3 - 4 leaves) was used for the experiments. Two consecutive experiments were conducted in duplicate. After measuring initial fresh weight, vine and root lengths (except for root length in the first experiment due to the absence of roots), the root part was dipped into the inoculants for $3 \mathrm{~min}$ and transplanted to the sterile pot, and $5 \mathrm{ml}$ inoculant was poured on the vermiculite around the plant. The inoculated plants were aseptically grown in a plant growth chamber (LH240S, Nippon medical and chemical instruments co., ltd, Japan) with a 14 hour photo period, $28^{\circ} \mathrm{C} / 25^{\circ} \mathrm{C}$ (day/night) at 7000 lux, which was provided by white fluorescent tubes. The same plant media without nitrogen was supplied to the bottom pot, as per the requirement. For control, sterile distilled water was inoculated. First experiment was conducted with nine inoculants and the better performing six inoculants were used in the second experiment.

The plants were harvested at 30 days after inoculation. The whole plant was carefully pulled to avoid damage and shaken to release loosely attached vermiculite, then strongly adhered vermiculite was manually removed with tweezers. 
After blotting excess moisture from the roots with absorbent paper, whole plant fresh weight, vine and root lengths were measured. Then, nitrogenase activity for the fresh roots was assayed by ARA using $100 \mathrm{ml}$ vial. Uninoculated plant roots with/without acetylene served as controls.

\subsection{Statistical Analysis}

All the statistical analyses were carried out using SPSS software package version 16.

\subsection{Nucleotide Sequence Accession Numbers}

All sequences are deposited in the DNA Data Bank of Japan (DDBJ) under accession numbers LC389337 to LC389579 (16S rRNA) and LC389580 to LC389582 (nifH gene).

\section{Results}

\subsection{Isolation and Identification of Endophytic Bacteria}

Different morphologies were observed among the appeared bacterial colonies, ranging from one to nine morphologies in Gulmi and Rupandehi locations, respectively. Two to 43 endophytic bacterial isolates per location, making a total of 243 isolates, were isolated and examined (Table S1).

Based on partial 16S rRNA gene sequencing analysis, 243 endophytic bacterial isolates were assigned to their close relatives, belonging to 34 bacterial genera in 6 classes (Table 2). Among the classes, Bacilli represented the highest relative abundance (28\%), and Bacillus sp. was the most dominant genus (25\%), followed by Gammaproteobacteria (22\%)/Enterobacter sp. (5.3\%), Betaproteobacteria (17\%)/Burkholderia sp. (8.6\%), Actinobacteria (16\%)/Microbacterium sp. (6.8\%), Alphaproteobacteria (14\%)/Rhizobium sp. (6.3\%) and Flavobacteriia (4.4\%)/Flavobacterium sp. (4.4\%).

\subsection{Distribution of Bacterial Genera}

Endophytic bacterial genera were distributed unevenly among the sweet potato samples (Table 2). Four bacterial genera commonly detected in at least five sampling sites were applied to the distribution analysis (Table 3). Enterobacter sp. and Microbacterium sp. were detected frequently in nutrient rich (copiotrophic) and poor (oligotrophic) soils, respectively. Bacillus sp. showed acidophilic nature while Rhizobium sp. and Microbacterium sp. were alkaliphilic. Similarly, Enterobacter sp. showed neutralophilic property. On the other hand, distribution of these four genera was unaffected by the temperature conditions.

PCA of the environmental parameters explained $41.3 \%$ and $40.6 \%$ of the variation in the first and second principal component factors, respectively, and showed that there are approximately two groupings, first being the high temperature and alkaline soils (Rupandehi, Banke-a and Banke-b) and second with the others (Figure 1(a)). PCA of bacterial class compositions explained $31.0 \%$ and 
R. R. Puri et al.

Table 2. Relative abundance of bacterial endophytes of sweet potato in Nepal.

\begin{tabular}{|c|c|c|c|c|c|c|c|c|c|c|c|c|c|}
\hline Sampling sites & Rolpa & Salyan & Gulmi & Palpa & Kavre-a & Kavre-b & Banke-a & Banke-b & Rupandehi & Chitwan & Sunsari-a & Sunsari-b & Total \\
\hline No. of colonies & 301 & 440 & 20 & 70 & 54 & 165 & 320 & 327 & 384 & 150 & 172 & 87 & 2490 \\
\hline No. of morphologies & 7 & 5 & 1 & 3 & 2 & 5 & 7 & 7 & 9 & 4 & 3 & 2 & 55 \\
\hline No. of isolates & 30 & 43 & 2 & 6 & 5 & 17 & 31 & 32 & 37 & 14 & 18 & 8 & 243 \\
\hline Class/genera & & & & & & & & & & & & & Average (\%) \\
\hline Flavobacteriia & 23 & 25 & & & & & 4.0 & & & & & & 4.4 \\
\hline Flavobacterium sp. & 23 & 25 & & & & & 4.0 & & & & & & 4.4 \\
\hline Bacilli & 16 & 3.0 & 100 & 32 & 22 & 51 & 3.0 & & 8.0 & 48 & 44 & 12 & 28 \\
\hline Bacillus sp. & & 3.0 & 100 & 43 & 22 & 37 & & & 3.0 & 48 & 44 & 12 & 25 \\
\hline Staphylococcus sp. & 16 & & & & & 13 & 3.0 & & & & & & 2.7 \\
\hline Exiguobacterium sp. & & & & & & & & & 3.0 & & & & 0.3 \\
\hline Paenibacillus sp. & & & & & & & & & 3.0 & & & & 0.3 \\
\hline Actinobacteria & 37 & 5.0 & & & & & 61 & 13 & 67 & & & & 16 \\
\hline Microbacterium sp. & 7.0 & 5.0 & & & & & 40 & 3.0 & 27 & & & & 6.8 \\
\hline Curtobacterium sp. & 23 & & & & & & 11 & 10 & 12 & & & & 4.6 \\
\hline Cellulomonas sp. & 23 & & & & & & 3.0 & & & & & & 2.0 \\
\hline Arthrobacter sp. & & & & & & & 6.8 & & 10 & & & & 1.0 \\
\hline Glutamicibacter sp. & & & & & & & & & 13 & & & & 1.0 \\
\hline Pseudarthrobacter sp. & & & & & & & & & 5.0 & & & & 0.4 \\
\hline Streptomyces sp. & 4.0 & & & & & & & & & & & & 0.3 \\
\hline Brachybacterium sp. & 3.0 & & & & & & & & & & & & 0.2 \\
\hline Alphaproteobacteria & & 11 & & 16 & 37 & 13 & 24 & 44 & 6.0 & 7.0 & 6.0 & & 14 \\
\hline Rhizobium sp. & & 9.0 & & 16 & & 13 & 6.0 & 19 & 6.0 & & 6.0 & & 6.3 \\
\hline Agrobacterium sp. & & 2.0 & & & 37 & & 6.0 & 13 & & & & & 4.8 \\
\hline Sphingobium sp. & & & & & & & & 13 & & & & & 1.0 \\
\hline Sphingomonas sp. & & & & & & & 12 & & & & & & 1.0 \\
\hline Neorhizobium sp. & & & & & & & & & & 7.0 & & & 0.6 \\
\hline Betaproteobacteria & 7.0 & 7.0 & & & 22 & 32 & & 10 & 13 & 22 & & 88 & 17 \\
\hline Burkholderia sp. & & & & & & & & & & 15 & & 88 & 8.6 \\
\hline Achromobacter sp. & & & & & & 19 & & & 13 & & & & 3.0 \\
\hline Herbaspirillum sp. & & 7.0 & & & 22 & 7.0 & & & & & & & 3.0 \\
\hline Xenophilus sp. & & & & & & & & 10 & & & & & 0.8 \\
\hline Massilia sp. & 7.0 & & & & & & & & & & & & 0.6 \\
\hline Paraburkholderia sp. & & & & & & & & & & 7.0 & & & 0.6 \\
\hline Caballeronia sp. & & & & & & 6.0 & & & & & & & 0.5 \\
\hline Gammaproteobacteria & 17 & 48 & & 51 & 19 & 4.2 & 6.0 & 33 & 6.0 & 23 & 50 & & 22 \\
\hline Enterobactersp. & 7.0 & 2.0 & & 33 & & & 3.0 & & & 7.0 & 11 & & 5.3 \\
\hline Pseudomonas sp. & & & & & 19 & & & & & & 39 & & 4.8 \\
\hline Stenotrophomonas sp. & 3.0 & 28 & & & & & & 12 & & 9.0 & & & 4.3 \\
\hline Luteibacter sp. & & & & 19 & & 1.0 & & & & & & & 1.7 \\
\hline Pantoea sp. & & & & & & 3.0 & 3.0 & & 6.0 & 7.0 & & & 1.6 \\
\hline Klebsiella sp. & & 18 & & & & & & & & & & & 1.5 \\
\hline Xanthomonas sp. & & & & & & & & 15 & & & & & 1.3 \\
\hline Pseudoxanthomonas sp. & & & & & & & & 6.0 & & & & & 0.5 \\
\hline Yokenella sp. & 6.0 & & & & & & & & & & & & 0.5 \\
\hline
\end{tabular}


Table 3. Detection frequency (\%) of the bacterial genera in different environmental conditions ${ }^{\mathrm{a}}$.

\begin{tabular}{|c|c|c|c|c|c|c|c|c|c|c|c|}
\hline \multirow{2}{*}{ Genera } & \multicolumn{2}{|c|}{ Phosphorus } & \multicolumn{2}{|c|}{ Carbon } & \multicolumn{2}{|c|}{ Nitrogen } & \multicolumn{3}{|c|}{$\mathrm{pH}$} & \multicolumn{2}{|c|}{ Temperature } \\
\hline & Low & High & Low & High & Low & High & Acidic & Neutral & Alkaline & Low & High \\
\hline Bacillus sp. & 83 & 67 & 71 & 80 & 83 & 67 & 100 & 83 & 33 & 83 & 67 \\
\hline Rhizobium sp. & 67 & 50 & 71 & 40 & 67 & 50 & 33 & 50 & 100 & 50 & 67 \\
\hline Enterobacter sp. & 33 & 67 & 29 & 80 & 17 & 83 & 0 & 83 & 33 & 50 & 50 \\
\hline Microbacterium sp. & 50 & 33 & 57 & 20 & 50 & 33 & 0 & 33 & 100 & 33 & 50 \\
\hline
\end{tabular}

${ }^{\mathrm{a}}$ : Low $\mathrm{P}\left(4.8-37 \mathrm{mg} \mathrm{kg}^{-1}\right.$ soil) and high $\mathrm{P}\left(87-379 \mathrm{mg} \mathrm{kg}^{-1}\right.$ soil), low C (4 - $11 \mathrm{~g} \mathrm{~kg}^{-1}$ soil) and high C (13 - $20 \mathrm{~g} \mathrm{~kg}^{-1}$ soil), low N (0.3 - $0.8 \mathrm{~g} \mathrm{~kg}$ soil) and high $\mathrm{N}\left(1.0-1.7 \mathrm{~g} \mathrm{~kg}^{-1}\right.$ soil), acidic $(\mathrm{pH} 5.5-5.9)$, neutral $(\mathrm{pH} 6.2-7.3)$ and alkaline $(\mathrm{pH} 8.0-8.4)$, high temperature $\left(34^{\circ} \mathrm{C}-39^{\circ} \mathrm{C}\right)$ and low temperature $\left(28^{\circ} \mathrm{C}-32^{\circ} \mathrm{C}\right)$.

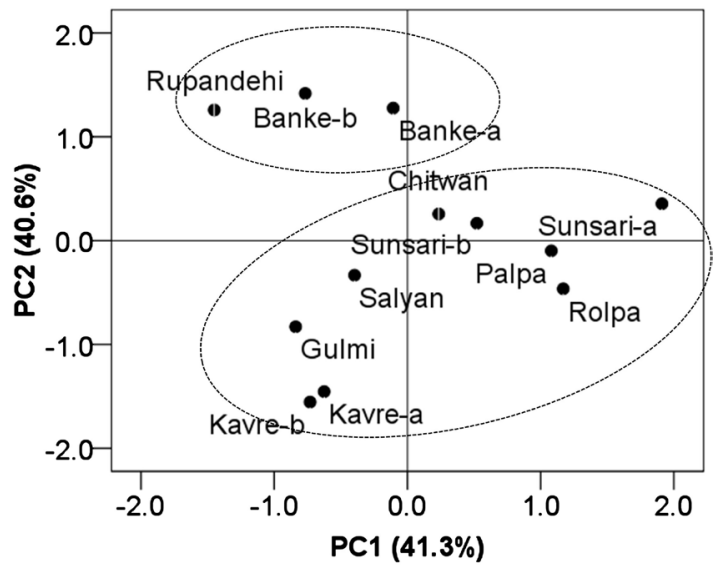

(a)

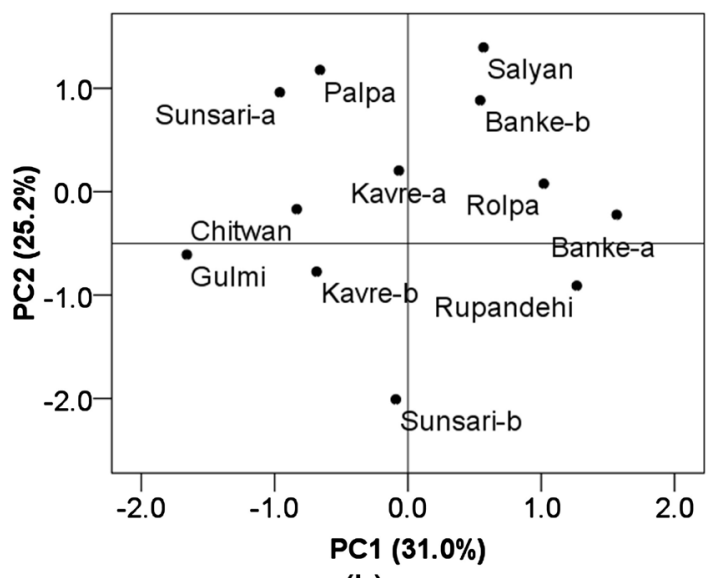

(b)

Figure 1. 2-D plot of principal component analysis of sampling locations based on (a) environmental parameters and (b) bacterial class composition in each location.

$25.2 \%$ of the variation in the first and second principal component factors, respectively, and revealed that the endophytic bacterial composition did not group as the environmental conditions (Figure 1(b)).

\subsection{Characterization of the Endophytic Bacterial Isolates}

Eighty three percent of the bacterial strains presented at least one of the charac- 
teristics examined. Within all the strains, 57\% produced IAA, 5.0\% had nifH gene and showed ARA activity, 37\% and $2.0 \%$ possessed antagonistic effect against the bacterial and the fungal pathogens, respectively. In addition, $17 \%$ and $8.0 \%$ showed cellulase and pectinase activities, respectively (Table 4).

Proportions of the bacterial class representing the examined traits were different (Table 4). IAA production was detected in the strains from Bacilli, Actinobacteria, Alpha- and Gamma-proteobacteria classes, and ARA activity was from Beta- and Gamma-proteobacteria. All the classes possessed antagonistic effect against the bacterial pathogens, while only Bacilli class showed the effect against the fungal pathogen. Almost all the bacterial classes showed cellulase activity while Alpa-, Beta- and Gamma-proteobacteria classes had pectinase activity.

Bacterial strains exhibiting at least one of the following plant growth promoting or endophytic traits are presented in Table 5: high IAA production ( $\geq 30$ $\mu \mathrm{g} / \mathrm{ml})$, ARA activity, strong antagonistic and cellulase/pectinase activities. Among the bacterial strains 8 of them showed higher IAA production potential with Ban-b 4 being the highest $(65 \mu \mathrm{g} / \mathrm{ml})$. Strains belonging to the same genus showed varying levels of IAA producing ability. In addition, Sal 1, Sal 6 and Rol 5 had nifH gene and showed the ARA activity with $54.5 \pm 7.3 \mathrm{nmol} \mathrm{C}_{2} \mathrm{H}_{4} / \mathrm{h} / \mathrm{vial}$, $39.9 \pm 1.9 \mathrm{nmol} \mathrm{C}_{2} \mathrm{H}_{4} / \mathrm{h} /$ vial and $8.9 \pm 0.8 \mathrm{nmol} \mathrm{C}_{2} \mathrm{H}_{4} / \mathrm{h} /$ vial, respectively.

Likewise, 11 bacterial strains showed strong antagonistic effect against at least one pathogen tested. Among them, Chi 2 and Gul 1 possessed strong activity against the tested bacterial pathogens and the latter showed strong activity against the fungal pathogen assayed. However, these two isolates did not show IAA producing ability. On the other hand, 5 bacterial strains showed cellulase activity while Ban-b 6 showed both cellulase and pectinase activity.

\subsection{Effect of Mixture of Endophytes on Plant Growth Promotion}

Fresh weight $(\mathrm{g})$, vine and root lengths $(\mathrm{cm})$ were considered for the assessment of plant growth promotion. Plantlets used in the experiments were non-uniform in size, and this might affect the parameters. So, times increase as compared to the control were used for the assessment of the plant growth promotion of the inoculants.

In the first experiment, the inoculated sweet potatoes showed higher values than control (Table 6). Mixture of isolates from Salyan, Palpa, Banke gained 3.18 - 3.51 times their initial weight whereas it was 1.6 in control. Likewise, gain in vine length ranged from 1.33 - 1.50 times for Kavre, Chitwan, Banke and Salyan inoculants, while it was 1.17 in control. Finally, the roots were longer in almost all inoculated plants than control.

Further, we selected six inoculants based on the first experiment and again evaluated. In the second experiment, the growth promoting effects were observed in fresh weight and vine length, but root lengths were shorter in the inoculated plants than control (Table 6). Among all the plants assessed, only Salyan 
Table 4. Bacterial class and their proportions having the plant growth promoting traits, antagonistic effect and endophytic traits.

\begin{tabular}{|c|c|c|c|c|c|c|c|c|c|c|}
\hline \multirow{2}{*}{ Class } & \multirow{2}{*}{$\begin{array}{l}\text { Number } \\
\text { of genera }\end{array}$} & \multirow{2}{*}{$\begin{array}{l}\text { Number } \\
\text { of strains }\end{array}$} & \multicolumn{2}{|c|}{ Plant growth promoting traits } & \multicolumn{4}{|c|}{ Antagonistic effect } & \multicolumn{2}{|c|}{ Endophytic traits } \\
\hline & & & IAA $^{\mathrm{a}}$ & ARA activity ${ }^{\mathrm{b}}$ & $\mathrm{ECa}^{\mathrm{c}}$ & $\mathrm{ECb}^{\mathrm{d}}$ & $E C c^{e}$ & Fungal $^{f}$ & Cellulase & Pectinase \\
\hline Flavobacteriia & 1 & 1 & 0 & 0 & 100 & 100 & 100 & 0 & 0 & 0 \\
\hline Bacilli & 4 & 7 & 43 & 0 & 29 & 43 & 28 & 14 & 14 & 0 \\
\hline Actinobacteria & 8 & 20 & 63 & 0 & 21 & 16 & 16 & 0 & 16 & 0 \\
\hline Alphaproteobacteria & 5 & 9 & 78 & 0 & 22 & 33 & 22 & 0 & 11 & 11 \\
\hline Betaproteobacteria & 7 & 8 & 0 & 13 & 25 & 25 & 25 & 0 & 13 & 13 \\
\hline Gammaproteobacteria & 9 & 15 & 75 & 13 & 19 & 25 & 6 & 0 & 25 & 19 \\
\hline Total & 34 & 60 & 57 & 5 & 27 & 58 & 25 & 2 & 17 & 8 \\
\hline
\end{tabular}

${ }^{\mathrm{a}}$ Indole-3-acetic acid $\left(\mu \mathrm{g} \mathrm{ml}^{-1}\right)$; ${ }^{\mathrm{b}}$ Acetylene reduction activity (nmol/h/vial); ${ }^{\mathrm{c}}$ Erwinia chrysanthemi NARCB200126, AZ9702; ${ }^{\mathrm{d}}$ Erwinia chrysanthemi E7725; ${ }^{\mathrm{e}}$ Erwinia chrysanthemi $\mathrm{T} 5-2$; ${ }^{\mathrm{f}}$ Pythium ultimum var ultimum OPU744.

Table 5. Plant growth promoting traits, antagonistic effect and endophytic traits of bacterial endophytes of sweet potato in Nepal.

\begin{tabular}{|c|c|c|c|c|c|c|c|c|c|c|}
\hline \multirow{2}{*}{ Class } & \multirow{2}{*}{ Strains } & \multirow{2}{*}{$\begin{array}{l}\text { Close relatives based on } \\
\text { 16S rRNA gene sequencing }\end{array}$} & \multicolumn{2}{|c|}{ Plant growth promoting traits } & \multicolumn{4}{|c|}{ Antagonistic effect ${ }^{c}$} & \multicolumn{2}{|c|}{ Endophytic traits ${ }^{c}$} \\
\hline & & & $\mathrm{IAA} / \mathrm{OD}^{\mathrm{a}}$ & ARA activity ${ }^{\mathrm{b}}$ & $\mathrm{ECa}^{\mathrm{d}}$ & $\mathrm{ECb}^{\mathrm{e}}$ & $E C c^{f}$ & Fungal $^{\mathrm{g}}$ & Cellulase & Pectinase \\
\hline \multirow[t]{2}{*}{ Bacilli } & Gul 1 & Bacillus sp. & 0 & - & ++ & ++ & ++ & ++ & ++ & - \\
\hline & Sun-a 3 & Bacillus sp. & 34 & - & - & - & - & - & - & - \\
\hline \multirow[t]{5}{*}{ Actinobacteria } & Rol 1 & Curtobacterium sp. & 0 & - & - & - & - & - & ++ & - \\
\hline & Sal 8 & Microbacterium sp. & 2 & - & + & + & ++ & - & - & - \\
\hline & Ban-a 5 & Arthrobacter sp. & 35 & - & - & - & - & - & - & - \\
\hline & Rup 2 & Microbacterium sp. & 11 & - & ++ & + & ++ & - & ++ & - \\
\hline & Rup 6 & Microbacterium sp. & 17 & - & ++ & + & - & - & - & - \\
\hline \multirow[t]{5}{*}{ Alphaproteobacteria } & Sal 7 & Agrobacterium sp. & 30 & - & + & + & - & - & - & - \\
\hline & Ban-a 3 & Agrobacterium sp. & 26 & - & - & ++ & - & - & - & - \\
\hline & Ban-a 4 & Rhizobium sp. & 28 & - & - & ++ & ++ & - & - & - \\
\hline & Ban-a 9 & Sphingomonas sp. & 8 & - & - & + & + & - & ++ & - \\
\hline & Ban b 4 & Sphingobium sp. & 65 & - & ++ & + & + & - & - & - \\
\hline \multirow[t]{3}{*}{ Betaproteobacteria } & Sal 6 & Herbaspirillum sp. & 0 & 9 & - & + & - & - & - & - \\
\hline & Chi 2 & Burkholderia sp. & 0 & - & ++ & ++ & ++ & - & - & - \\
\hline & Sun-b 1 & Burkholderia sp. & 0 & - & ++ & + & + & - & + & - \\
\hline \multirow[t]{7}{*}{ Gammaproteobacteria } & Rol 5 & Yokenella sp. & 36 & 40 & - & - & - & - & - & - \\
\hline & Sal 1 & Klebsiella sp. & 48 & 55 & - & + & - & - & + & - \\
\hline & Sal 3 & Enterobactersp. & 61 & - & - & + & - & - & - & + \\
\hline & Kav-b 3 & Luteibactersp. & 15 & - & ++ & - & - & - & - & - \\
\hline & Ban-a 7 & Pantoea sp. & 29 & - & ++ & ++ & - & - & + & - \\
\hline & Ban-b 6 & Pseudoxanthomonas sp. & 13 & - & - & + & - & - & ++ & ++ \\
\hline & Chi 1 & Pantoea sp. & 36 & - & - & + & - & - & ++ & - \\
\hline
\end{tabular}

${ }^{\mathrm{a}}$ Indole-3-acetic acid $\left(\mu \mathrm{g} \mathrm{ml}^{-1}\right)$ optical density ${ }^{-1}$; ${ }^{\mathrm{b}}$ Acetylene reduction activity $(\mathrm{nmol} / \mathrm{h} / \mathrm{vial}) ;{ }^{\mathrm{c}}{ }^{-},+$and ++ denote no, weak and strong activities, respectively; ${ }^{\mathrm{d}}$ Erwinia chrysanthemi NARCB200126, AZ9702; ${ }^{\mathrm{e}}$ Erwinia chrysanthemi E7725; ${ }^{\mathrm{f}}$ Erwinia chrysanthemi $\mathrm{Ech}$ T5-2; ${ }^{\mathrm{g}}$ Pythium ultimum var ultimum OPU744. 
Table 6. Times increase in growth parameters of sweet potato plants $(n=2)$.

\begin{tabular}{|c|c|c|c|c|c|c|}
\hline \multirow{2}{*}{ Inoculants } & \multicolumn{3}{|c|}{ First Experiment } & \multicolumn{3}{|c|}{ Second experiment } \\
\hline & Fresh weight & Vine length & Root length $^{\mathrm{b}}$ & Fresh weight & Vine length & Root length \\
\hline Rolpa & 2.63 & 1.17 & 59 & - & - & - \\
\hline Salyan & 3.51 & 1.33 & 73 & 5.70 & 1.53 & 7.2 \\
\hline Gulmi & 2.31 & 1.28 & 68 & - & - & - \\
\hline Palpa & 3.33 & 1.26 & 76 & 7.56 & 1.45 & 18.7 \\
\hline Kavre & 2.59 & 1.50 & 66 & 10.20 & 2.33 & 22.4 \\
\hline Banke & 3.18 & 1.33 & 50 & 9.45 & 1.50 & 34.2 \\
\hline Rupandehi & 2.25 & 1.21 & 75 & 5.86 & 2.14 & 21.0 \\
\hline Chitwan $^{\mathrm{a}}$ & 2.99 & 1.35 & 74 & 4.98 & 1.00 & 25.0 \\
\hline Sunsari ${ }^{\mathrm{a}}$ & 2.80 & 1.16 & 70 & - & - & - \\
\hline Control & 1.60 & 1.17 & 47 & 4.68 & 1.24 & 38.0 \\
\hline
\end{tabular}

${ }^{a}$ Data from one replication is considered for Sunsari and Chitwan in first and second experiment respectively, as one replication plant was dead; ${ }^{\mathrm{b}}$ Final root length $(\mathrm{cm})$.

isolates inoculated plants showed ARA activity $(0.09 \mathrm{nmol} / \mathrm{h} / \mathrm{g})$.

\section{Discussion}

In the present study, culture dependent method was used to learn more about the endophytic bacterial community in sweet potato collected from Nepal. In analyzing endophytic communities by culture dependent methods, most researchers selected dominant single colonies representing distinct morphology and ignored minor ones and therefore their diversity [27] [28] [29] [30] [31]. On the other hand, we examined all colonies in the plates and grouped based on their morphologies, and the representative colony (s) in each group was selected on the basis of their relative abundance for further analysis. Our method would be more reliable in examining the endophytic communities.

In culture dependent methods, media components are the most influential parameter. Marques et al. used three media conditions (TSA, PDA and modified $\mathrm{RM}$ ) and isolated 93 endophytic bacteria belonging to 17 genera for three sweet potato cultivars collected in Brazil [6]. Although the media used were different, the following common genera were mainly detected: Bacillus sp. and Paenibacillus sp. in Bacilli class, Arthrobacter sp. and Microbacterium sp. in Actinobacteria, Sphingomonas sp. and Rhizobium sp. in Alphaproteobacteria and Enterobacter sp., Pantoea sp. and Pseudomonas sp. in Gammaproteobacteria. This result was similar to our result even though the media and cultivation locations were different. Khan and Doty isolated 11 endophytes in seven genera by MS medium from sweet potatoes collected from grocery store in USA [7], where Stenotrophomonas sp., Pseudomonas sp., Enterobacter sp. and Xanthomonas sp. in Gammaproteobacteria were dominated. Gammaproteobacteria have been reported as commonly dominant endophyte in plants [32]. On the other hand, 
isolates from Bacilli class was not detected [7] demonstrating that the Bacilli might not always be dominated in sweet potato. More studies are necessary to make better conclusions for endophytic dominancy of Bacilli in sweet potato. Hardoim et al. reported that Bacilli is not dominantly detected as endophyte in many plants [32], whereas, they have been dominantly detected in several crops as canola [33], banana [34], switch grass [35] and tobacco [36]. The determining factors of Bacilli are still unclear and needs to be explored.

Culture dependent methods have a limitation of analyzing microbial communities due to unknown conditions for growth requirements of many bacteria and presence of the viable but noncultivable state [37]. As a result, the dominant bacterial endophytes could not always be isolated. For example, Ralstonia sp. was dominant in culture independent methods in salad crops [31] and sweet potato [6], but it was not isolated from the samples. Likewise, Enterobacter sp. dominantly detected in culture independent methods in maize was not isolated [38]. In our study, we could not successfully amplify the bacterial DNA from the sweet potato DNA using LNA-PCR technique [39] and the possible reason is unknown. The culture dependent method has its own limitation on determining the bacterial community but it is only the option to isolate the bacteria for their functional analysis. It is important to find the suitable culture conditions for the endophytes. Modification of media components considering their natural habitat could be one of the options.

There have been relatively a few studies that have analyzed the effects of environmental variables on endophyte diversity [40]. For example, culturable endophytic bacterial communities were more diverse in tobacco roots from organic soils compared to those grown in mineral soils [36]. Similarly, psychrophilic bacterial endophytes were isolated abundantly in cold environments from the arcto-alpine plant species [41]. Likewise, culturable endophytic bacterial communities in four vegetable crops were more diverse in organic farming practices as compared to conventional ones [42].

The colonization of endophytic bacterial community could be influenced by environmental conditions through the following two processes. Firstly, environmental variables affect the plant physiology thereby influencing the root exudates which might determine the microbial communities in the rhizosphere, the potential endophytic candidates [33] [43] [38]. It was reported that environmental factors such as temperatures and photon flux density influenced root exudates of tomato and clover [44]. Likewise, low photon flux density increased the release of carbon in root exudates of rye grass [45]. In addition, it was also reported that oxalate in the root exudates enriched Oxalobacteraceae family in the rhizosphere of stiff brome plant [46]. Similarly, Haichar et al. reported that the rape plant root exudates enriched the rhizospheric zone with Alpha-, Delta-, Beta- and Gamma-proteobacteria and Actinobacteria, barrel clover with Alphaand Gamma-proteobacteria, and maize with Alpha-, Beta-, Gamma-proteobacteria and Actinobacteria [47]. 
Secondly, environmental variables influence the bacterial composition in the bulk soil which ultimately determines the possible endophytic community [48]. Although several environmental factors are responsible in determining the soil bacterial community, soil $\mathrm{pH}$ is one of the influencing parameters. In a diverse set of ecosystems across South and North America, soil bacterial community was strongly shaped by soil $\mathrm{pH}$ at the continental scale, where bacterial diversity was highest in neutral soils and lower in acidic soils [49]. Similarly, the relative abundance of Actinobacteria, Bacterioidetes, Fibrobacteres and Firmicutes was higher at near-neutral $\mathrm{pH}$ and lower at acidic and alkaline $\mathrm{pH}$ [50]. In addition, temperature is one of the environmental factors determining the composition of the soil bacterial community. Studies conducted applying culture independent methods revealed that the relative abundances of Actinobacteria and Firmicutes increased at higher temperatures, while Bacteroidetes and Deltaproteobacteria showed the opposite pattern when the soils collected from an alpine meadow were incubated at different temperatures [51]. Similarly, Lin et al. reported that the relative abundance of soil Acidobacteria decreased with increasing temperature while Gammaproteobacteria increased [52]. Thus, environmental conditions influenced on the endophytic bacterial community by changing the profile of plant exudates resulting in selection of distinct rhizobacterial community and by influencing the soil microbial community; the main sources for endophytic community.

There are reports that the plant determines the endophytic bacterial communities and soil factors played a minor role [33]. Other researchers, however, have reported that soil type [53] [54] and environmental factors [53] determine the endophytic communities. Our results indicate that endophytic diversity is independent on soil and environmental factors. Hence, it was suggested that the plant and other unknown factors would be responsible in determining the endophytic bacterial community.

Plant growth promoting and endophytic characteristics of the selected bacterial isolates were analyzed in this study using in vitro tests. IAA is the main phytohormone in plants, regulating many important physiological processes including cell enlargement and division, tissue differentiation, and responses to light [17]. In our study, 57\% of endophytic bacteria isolated from sweet potato synthesized IAA from tryptophan, and the ability was distributed to Bacilli, Actinobacteria, Alpha- and Gamma-proteobacteria classes. Similarly, IAA producing endophytes in the same classes have been reported in sweet potato [6] [7] and the other crops as rice [55], ginseng [56], semi-aquatic grass [57] and poplar trees [58]. The IAA producing endophytes can be used as plant growth promoting agent, but the ability should be confirmed in in situ conditions.

Among the tested endophytes, only three strains (5\%) showed the $\mathrm{N}_{2}$-fixing potential. Similarly, detection of nifH in endophytic isolates was negative in sweet potato [6] or not often in rice [55] and ginseng [56], representing $2 \%$ and $4 \%$ of the total isolates, respectively. As their presence might play a role in the 
growth of sweet potato plants, it is thus, necessary to determine how much nitrogen they fix in the host plant.

Endophytic bacteria from all the classes demonstrated the antagonistic effect against the bacterial pathogens, while antagonism against the fungal pathogen was observed only for Bacilli class represented by Bacillus sp. Gul 1. In congruent to our findings, Marques et al. reported that Bacillus sp. isolated as endophytes from sweet potato tubers showed antimicrobial activity against a fungal pathogen, Plenodomus destruens [6]. Because it was reported that some of the Bacillus strains produce antimicrobial compounds as iturins that affect fungal signaling pathways [59] and surfactin, an antifungal lipopeptide [60], Bacillus sp. Gul 1 might produce antifungal compounds.

Besides all these plant growth promoting properties, endophytes need to colonize inside the host plants. Except for already established seed endophytes [61], common points of entry are through stomata [62], primary and lateral root cracks and tissues wounds created as a result of plant growth [63]. Besides these pathways, presence of the hydrolytic enzymes in sweet potato endophytes suggests enzyme based penetration of these endophytes to the plant.

The inoculation of crop plants with beneficial microbes is a practice used in agriculture and provides advantages to crops by enhancing plant growth and triggering protection to diseases [55]. It was also reported that the inoculation with multiple beneficial bacteria have higher potential than inoculation with a single bacterial inoculant [12] [64]. Our study also showed the positive effects when the isolates were applied as a mixture from each location. Mixture of inoculants might interact synergistically to provide nutrients, remove inhibitory products and stimulate one another.

Plant growth promotions by the IAA producing endophytes have been reported in sweet potato [7] and other crops as tomato [65] and strawberry [66]. In our study, all inoculants with plant growth promoting activity included the IAA producing endophytic bacteria suggesting that IAA produced influenced the growth. In addition, sweet potato inoculated with Salyan mixture including nifH gene containing Klebsiella sp. Sal 1 and Herbaspirillum sp. Sal 6 showed ARA activity suggesting that $\mathrm{N}$-fixation would be one of the reasons for the higher fresh weight of the inoculated plants.

In this study, it was difficult to prepare the test plants with similar initial size, and the bigger the initial size produced the bigger plant. Therefore, times increase of fresh weight, vine length and root length were used to compare the plant growth promoting effect. Although, the times increase were not constant in the repeated experiments, we could observe the positive effect of the inoculants. This suggests the endophytic community possess potential for plant growth promotion.

\section{Conclusion}

Further studies will be necessary to determine the responsible endophytes and 
their mechanisms of the plant growth promotion, but community might be important and necessary for the ability. Besides this, scope still exists to unravel the endophytic community structure by culture independent method and to cultivate the uncultured endophytes by modifying the culture conditions. Although the in vitro assays used may not reproduce exactly the conditions of natural environment, they can provide rapid screening of the potential strains, which can save time and costs, and further screening for the candidates in situ is necessary.

\section{Conflicts of Interest}

The authors declare no conflicts of interest regarding the publication of this paper.

\section{References}

[1] Hartemink, A.E., Poloma, S., Maino, M., Powell, K.S., Egenae, J. and O'Sullivan, J.N. (2000) Yield Decline of Sweet Potato in the Humid Lowlands of Papua New Guinea. Agriculture, Ecosystems and Environment, 79, 259-269. https://doi.org/10.1016/S0167-8809(00)00139-0

[2] Hill, W.A., Hortense, D., Hahn, S.K., Mulongoy, K. and Adeyeye, S.O. (1990) Sweet Potato Root and Biomass Production with and without Nitrogen Fertilization. Agronomy Journal, 82, 1120. https://doi.org/10.2134/agronj1990.00021962008200060019x

[3] Adachi, K., Nakatani, M. and Mochida, H. (2002) Isolation of an Endophytic Diazotroph, Klebsiella oxytoca, from Sweet Potato Stems in Japan. Soil Science and Plant Nutrition, 48, 889-895. https://doi.org/10.1080/00380768.2002.10408717

[4] Asis, C.A. and Adachi, K. (2004) Isolation of Endophytic Diazotroph Pantoea agglomerans and Nondiazotroph Enterobacter asburiae from Sweet Potato Stem in Japan. Letters in Applied Microbiology, 38, 19-23.

https://doi.org/10.1046/j.1472-765X.2003.01434.x

[5] Döbereiner, J., Baldani, V.L. and Reis, V.M. (1995) Endophytic Occurrence of Diazotrophic Bacteria in Non-Leguminous Crops. In: Azospirillum VI and Related Microorganisms, Springer, Berlin, 3-14. https://doi.org/10.1007/978-3-642-79906-8_1

[6] Marques, J.M., da Silva, T.F., Vollú, R.E., de Lacerda, J.R.M., Blank, A.F., Smalla, K., et al. (2015) Bacterial Endophytes of Sweet Potato Tuberous Roots Affected by the Plant Genotype and Growth Stage. Applied Soil Ecology, 96, 273-281.

https://doi.org/10.1016/j.apsoil.2015.08.020

[7] Khan, Z. and Doty, S.L. (2009) Characterization of Bacterial Endophytes of Sweet Potato Plants. Plant and Soil, 322, 197-207. https://doi.org/10.1007/s11104-009-9908-1

[8] Bhattarai, P. (2015) Sweet Potato Research for Enhancing Food and Nutrition Security in Nepal. Journal of Horticulture, Forestry and Biotechnology, 19, 62-70. https://www.cabdirect.org/cabdirect/abstract/20163140134

[9] FAOSTAT (2018) http://fenix.fao.org/faostat/internal/en/\#home

[10] Adhikari, D., Kaneto, M., Itoh, K., Suyama, K., Pokharel, B.B. and Gaihre, Y.K. (2012) Genetic Diversity of Soybean-Nodulating Rhizobia in Nepal in Relation to Climate and Soil Properties. Plant and Soil, 357, 131-145.

https://doi.org/10.1007/s11104-012-1134-6 
[11] Oliveira, A.L.M., Urquiaga, S., Döbereiner, J. and Baldani, J.I. (2002) The Effect of Inoculating Endophytic N2-Fixing Bacteria on Micropropagated Sugarcane Plants. Plant and Soil, 242, 205-215. https://doi.org/10.1023/A:1016249704336

[12] Molina-Romero, D., Baez, A., Quintero-Hernández, V., Castañeda-Lucio, M., Fuentes-Ramírez, L.E., del Rocio Bustillos-Cristales, M., et al. (2017) Compatible Bacterial Mixture, Tolerant to Desiccation, Improves Maize Plant Growth. PLoS ONE, 12, 1-21. https://doi.org/10.1371/journal.pone.0187913

[13] McLean, E.O. (1982) Soil pH and Lime Requirement. In: Page, A.L., Miller, R.H. and Keeney, D.R., Eds., Methods of Soil Analysis. Part 2-Chemical and microbiological Properties, 2nd Ed., Agronomy, Madison, Wisconsin, 199-223.

[14] Olsen, S.R., Cole, C.V., Watanabe, F.S. and Dean, L.A. (1954) Estimation of Available Phosphorus in Soils by Extraction with Sodium Bicarbonate. Circular, 939, 19.

[15] Weisburg, W.G., Barns, S.M., Pelletier, D.A. and Lane, D.J. (1991) 16S Ribosomal DNA Amplification for Phylogenetic Study. Journal of Bacteriology, 173, 697-703. https://doi.org/10.1128/jb.173.2.697-703.1991

[16] Altschul, S.F., Madden, T.L., Schäffer, A.A., Zhang, J., Zhang, Z., Miller, W., et al. (1997) Gapped BLAST and PSI-BLAST: A New Generation of Protein Database Search Programs. Nucleic Acids Research, 25, 3389-3402.

https://doi.org/10.1093/nar/25.17.3389

[17] Gordon, S.A. and Weber, R.P. (1951) Colorimetric Estimation of Inodoleacetic Acid. Plant Physiology, 26, 192-195. https://doi.org/10.1104/pp.26.1.192

[18] Poly, F., Monrozier, L.J. and Bally, R. (2001) Improvement in the RFLP Procedure for Studying the Diversity of nifH Genes in Communities of Nitrogen Fixers in Soil. Research in Microbiology, 152, 95-103. https://doi.org/10.1016/S0923-2508(00)01172-4

[19] Elbeltagy, A., Nishioka, K., Sato, T., Suzuki, H., Ye, B., Hamada, T., et al. (2001) Endophytic Colonization and in Planta Nitrogen Fixation by a Herbaspirillum sp. Isolated from Wild Rice Species Endophytic Colonization and in Planta Nitrogen Fixation by a Herbaspirillum sp. Isolated from Wild Rice Species. Applied and Environmental Microbiology, 67, 5285-5293. https://doi.org/10.1128/AEM.67.11.5285-5293.2001

[20] Zhao, L., Xu, Y., Sun, R., Deng, Z., Yang, W. and Wei, G. (2011) Identification and Characterization of the Endophytic Plant Growth Prompter Bacillus cereus Strain MQ23 Isolated from Sophora alopecuroides Root Nodules. Brazilian Journal of Microbiology, 42, 567-575. https://doi.org/10.1590/S1517-83822011000200022

[21] Someya, T. (1980) Counting Methods of Aerobic Cellulose Decomposers in Paddy Soils. Reports of the Institute for Agricultural Research, Tohoku University, 31, 43-58.

[22] Suyama, K., Yamamoto, H., Naganawa, T., Iwata, T. and Komada, H. (1993) A Plate Count Method for Aerobic Cellulose Decomposers in Soil by Congo Red Staining. Soil Science and Plant Nutrition, 39, 361-365. https://doi.org/10.1080/00380768.1993.10417008

[23] Ma, Y., Rajkumar, M., Luo, Y.M. and Freitas, H. (2011) Inoculation of Endophytic Bacteria on Host and Non-Host Plants-Effects on Plant Growth and Ni Uptake. Journal of Hazardous Materials, 195, 230-237. https://doi.org/10.1016/j.jhazmat.2011.08.034

[24] Leonard, L.T. (1943) A Simple Assembly for Use in the Testing of Cultures of Rhizobia. Journal of Bacteriology, 45, 523-527.

https://www.ncbi.nlm.nih.gov/pmc/articles/PMC373773/ 
[25] Hoagland, D.R. and Arnon, D.I. (1950) The Water-Culture Method for Growing Plants without Soil. California Agricultural Experiment Station Circular, 347, 1-32.

[26] Soil Survey Staff (1999) Soil Taxonomy. A Basic System of Soil Classification for Making and Interpreting Soil Surveys. USDA Agriculture Handbook No. 436. U.S. Government Print Office, Washington DC. https://www.nrcs.usda.gov/Internet/FSE_DOCUMENTS/nrcs142p2_051232.pdf

[27] Fredrickson, J.K., Balkwill, D.L., Zachara, J.M., Li, S.W., Brockman, F.J. and Simmons, M. (1991) Physiological Diversity and Distributions of Heterotrophic Bacteria in Deep Cretaceous Sediments of the Atlantic Coastal Plain Physiological Diversity and Distributions of Heterotrophic Bacteria in Deep Cretaceous Sediments of the Atlantic Coastal Plain. Applied and Environmental Microbiology, 57, 402-411. http://digitalcommons.unl.edu/usdoepub/178

[28] McInroy, J.A. and Kloepper, J.W. (1995) Survey of Indigenous Bacterial Endophytes from Cotton and Sweet Corn. Plant and Soil, 173, 337-342.

https://doi.org/10.1007/BF00011472

[29] Lebaron, P., Ghiglione, J.F., Fajon, C., Batailler, N. and Normand, P. (1998) Phenotypic and Genetic Diversity within a Colony Morphotype. FEMS Microbiology Letters, 160, 137-143. https://doi.org/10.1111/j.1574-6968.1998.tb12903.x

[30] Tiwari, R., Kalra, A., Darokar, M.P., Chandra, M., Aggarwal, N., Singh, A.K., et al. (2010) Endophytic Bacteria from Ocimum sanctum and Their Yield Enhancing Capabilities. Current Microbiology, 60, 167-171. https://doi.org/10.1007/s00284-009-9520-x

[31] Jackson, C.R., Randolph, K.C., Osborn, S.L. and Tyler, H.L. (2013) Culture Dependent and Independent Analysis of Bacterial Communities Associated with Commercial Salad Leaf Vegetables. BMC Microbiology, 13, 1-12. https://doi.org/10.1186/1471-2180-13-274

[32] Hardoim, P.R., van Overbeek, L.S., Berg, G., Pirttilä, A.M., Compant, S., Campisano, A., et al. (2015) The Hidden World within Plants: Ecological and Evolutionary Considerations for Defining Functioning of Microbial Endophytes. Microbiology and Molecular Biology Reviews, 79, 293-320. https://doi.org/10.1128/MMBR.00050-14

[33] Germida, J.J., Siciliano, S.D., de Freitas, J.R. and Seib, A.M. (1998) Diversity of Root-Associated Bacteria Associated with Held-Grown Canola (Brassica napus L.) and Wheat (Triticum aestivum L.). FEMS Microbiology Ecology, 26, 43-50. https://doi.org/10.1111/j.1574-6941.1998.tb01560.x

[34] Souza, S.A., Xavier, A.A., Costa, M.R., Cardoso, A.M.S., Pereira, M.C.T. and Nietsche, S. (2013) Endophytic Bacterial Diversity in Banana "Prata Anã" (Musa spp.) Roots. Genetics and Molecular Biology, 36, 252-264.

https://doi.org/10.1590/S1415-47572013000200016

[35] Xia, Y., Greissworth, E., Mucci, C., Williams, M.A. and DeBolt, S. (2013) Characterization of Culturable Bacterial Endophytes of Switchgrass (Panicum virgatum L.) and Their Capacity to Influence Plant Growth. GCB Bioenergy.

[36] Long, H.H., Sonntag, D.G., Schmidt, D.D. and Baldwin, I.T. (2010) The Structure of the Culturable Root Bacterial Endophyte Community of Nicotiana attenuata Is Organized by Soil Composition and Host Plant Ethylene Production and Perception. New Phytologist, 185, 554-567. https://doi.org/10.1111/j.1469-8137.2009.03079.x

[37] Tholozan, J.L., Cappelier, J.M., Tissier, J.P., Delattre, G. and Federighi, M. (1999) Physiological Characterization of Viable-But-Nonculturable Campylobacter jejuni Cells. Applied and Environmental Microbiology, 65, 1110-1116. 
https://www.ncbi.nlm.nih.gov/pmc/articles/PMC91151/

[38] Pereira, P., Ibáñez, F., Rosenblueth, M., Etcheverry, M. and Martínez-Romero, E. (2011) Analysis of the Bacterial Diversity Associated with the Roots of Maize (Zea mays L.) through Culture-Dependent and Culture-Independent Methods. ISRN Ecology, 2011, Article ID: 938546. https://doi.org/10.5402/2011/938546

[39] Ikenaga, M. and Sakai, M. (2014) Application of Locked Nucleic Acid (LNA) Oligonucleotide-PCR Clamping Technique to Selectively PCR Amplify the SSU rRNA Genes of Bacteria in Investigating the Plant-Associated Community Structures. $\mathrm{Mi}$ crobes and Environments, 29, 286-295. https://doi.org/10.1264/jsme2.ME14061

[40] Santoyo, G., Moreno-Hagelsieb, G., del Carmen Orozco-Mosqueda, M. and Glick, B.R. (2016) Plant Growth-Promoting Bacterial Endophytes. Microbiological Research, 183, 92-99. https://doi.org/10.1016/j.micres.2015.11.008

[41] Nissinen, R.M., Männistö, M.K. and van Elsas, J.D. (2012) Endophytic Bacterial Communities in Three Arctic Plants from Low Arctic Fell Tundra Are Cold-Adapted and Host-Plant Specific. FEMS Microbiology Ecology, 82, 510-522. https://doi.org/10.1111/j.1574-6941.2012.01464.x

[42] Xia, Y., DeBolt, S., Dreyer, J., Scott, D. and Williams, M.A. (2015) Characterization of Culturable Bacterial Endophytes and Their Capacity to Promote Plant Growth from Plants Grown Using Organic or Conventional Practices. Frontiers in Plant Science, 6, 490. https://doi.org/10.3389/fpls.2015.00490

[43] Marquez-Santacruz, H.A., Hernandez-Leon, R., Orozco-Mosqueda, M.C., Velazquez-Sepulveda, I. and Santoyo, G. (2010) Diversity of Bacterial Endophytes in Roots of Mexican Husk Tomato Plants (Physalis ixocarpa) and Their Detection in the Rhizosphere. Genetic and Molecular Research, 9, 2372-2380. https://doi.org/10.4238/vol9-4gmr921

[44] Rovira, A.D. (1959) Root Excretions in Relation to the Rhizosphere Effect. IV. Influence of Plant Species, Age of Plant, Light, Temperature, and Calcium Nutrition on Exudation. Plant and Soil, 11, 53-64. https://doi.org/10.1007/BF01394753

[45] Hodge, A., Paterson, E., Thornton, B., Millard, P. and Killham, K. (1997) Effects of Photon Flux Density on Carbon Partitioning and Rhizosphere Carbon Flow of Lolium perenne Management Options for Increasing Soil Carbon under Grasslands View Project Effects of Photon Flux Density on Carbon Partitioning and Rhizosphere Carbon fl. Journal of Experimental Botany, 48, 1797-1805. https://doi.org/10.1093/jxb/48.10.1797

[46] Kawasaki, A., Donn, S., Ryan, P.R., Mathesius, U., Devilla, R., Jones, A., et al. (2016) Microbiome and Exudates of the Root and Rhizosphere of Brachypodium distachyon, a Model for Wheat. PLOS ONE, 11, e0164533. https://doi.org/10.1371/journal.pone.0164533

[47] Haichar, F.E.Z., Marol, C., Berge, O., Rangel-Castro, J.I., Prosser, J.I., Balesdent, J., et al. (2008) Plant Host Habitat and Root Exudates Shape Soil Bacterial Community Structure. ISME Journal, 2, 1221-1230. https://doi.org/10.1038/ismej.2008.80

[48] Hallmann, J., Quadt-Hallmann, A., Mahaffee, W.F. and Kloepper, J.W. (1997) Bacterial Endophytes in Agricultural Crops. Canadian Journal of Microbiology, 43, 895-914. https://doi.org/10.1139/m97-131

[49] Fierer, N. and Jackson, R.B. (2006) The Diversity and Biogeography of Soil Bacterial Communities. PNAS, 103, 626-631. https://doi.org/10.1073/pnas.0507535103

[50] Zhang, Y., Shen, H., He, X., Thomas, B.W., Lupwayi, N.Z., Hao, X., et al. (2017) Fertilization Shapes Bacterial Community Structure by Alteration of Soil pH. Fron- 
tiers in Microbiology, 8, 1325. https://doi.org/10.3389/fmicb.2017.01325

[51] Wu, J., Xiong, J., Hu, C., Shi, Y., Wang, K. and Zhang, D. (2015) Temperature Sensitivity of Soil Bacterial Community along Contrasting Warming Gradient. Applied Soil Ecology, 94, 40-48. https://doi.org/10.1016/j.apsoil.2015.04.018

[52] Lin, Y.-T., Jia, Z., Wang, D. and Chiu, C.-Y. (2017) Effects of Temperature on the Composition and Diversity of Bacterial Communities in Bamboo Soils at Different Elevations. Biogeosciences, 14, 4879-4889. https://doi.org/10.5194/bg-14-4879-2017

[53] Gaiero, J.R., McCall, C.A., Thompson, K.A., Day, N.J., Best, A.S. and Dunfield, K.E. (2013) Inside the Root Microbiome: Bacterial Root Endophytes and Plant Growth Promotion. American Journal of Botany, 100, 1738-1750. https://doi.org/10.3732/ajb.1200572

[54] Prischl, M., Hackl, E., Pastar, M., Pfeiffer, S. and Sessitsch, A. (2012) Genetically Modified Bt Maize Lines Containing cry $3 B b 1$, cryl $A 105$ or cry $A b 2$ Do Not Affect the Structure and Functioning of Root-Associated Endophyte Communities. Applied Soil Ecology, 54, 39-48. https://doi.org/10.1016/j.apsoil.2011.12.005

[55] Ji, S.H., Gururani, M.A. and Chun, S.C. (2014) Isolation and Characterization of Plant Growth Promoting Endophytic Diazotrophic Bacteria from Korean Rice Cultivars. Microbiological Research, 169, 83-98. https://doi.org/10.1016/j.micres.2013.06.003

[56] Vendan, R.T., Yu, Y.J., Lee, S.H. and Rhee, Y.H. (2010) Diversity of Endophytic Bacteria in Ginseng and Their Potential for Plant Growth Promotion. Journal of Microbiology, 48, 559-565. https://doi.org/10.1007/s12275-010-0082-1

[57] Jha, P.N. and Kumar, A. (2007) Endophytic Colonization of Typha australis by a Plant Growth-Promoting Bacterium Klebsiella oxytoca Strain GR-3. Journal of Applied Microbiology, 103, 1311-1320. https://doi.org/10.1111/j.1365-2672.2007.03383.x

[58] Taghavi, S. and van der Lelie, D. (2013) Genome Sequence of the Plant Growth-Promoting Endophytic Bacterium Enterobacter sp. 638. Molecular Microbial Ecology of the Rhizosphere, 2, 899-908. https://doi.org/10.1002/9781118297674.ch84

[59] Han, Q., Wu, F., Wang, X., Qi, H., Shi, L., Ren, A., et al. (2015) The Bacterial Lipopeptide Iturins Induce Verticillium dahliae Cell Death by Affecting Fungal Signalling Pathways and Mediate Plant Defence Responses Involved in Pathogen-Associated Molecular Pattern-Triggered Immunity. Environmental Microbiology, 17, 1166-1188.

[60] Tendulkar, S.R., Saikumari, Y.K., Patel, V., Raghotama, S., Munshi, T.K. and Balaram, P. (2007) Isolation, Purification and Characterization of an Antifungal Molecule Produced by Bacillus licheniformis BC98, and Its Effect on Phytopathogen Magnaporthe grisea. Journal of Applied Microbiology, 103, 2331-2339.

[61] Truyens, S., Weyens, N., Cuypers, A. and Vangronsveld, J. (2015) Bacterial Seed Endophytes: Genera, Vertical Transmission and Interaction with Plants. Environmental Microbiology Reports, 7, 40-50. https://doi.org/10.1111/1758-2229.12181

[62] Roos, I.M.M. and Hattingh, M.J. (1983) Scanning Electron Microscopy of Pseudomonas syringae pv, morsprunorum on Sweet Cherry Leaves. Journal of Phytopathology, 108, 18-25. https://doi.org/10.1111/j.1439-0434.1983.tb00559.x

[63] Sprent, J.I. and De Faria, S.M. (1989) Mechanisms of Infection of Plants by Nitrogen Fixing Organisms. In: Nitrogen Fixation with Non-Legumes, Springer, Dordrecht, 3-11. https://doi.org/10.1007/978-94-009-0889-5_1 
[64] Oliveira, A.L.M., Stoffels, M., Schmid, M., Reis, V.M., Baldani, J.I. and Hartmann, A. (2009) Colonization of Sugarcane Plantlets by Mixed Inoculations with Diazotrophic Bacteria. European Journal of Soil Biology, 45, 106-113. https://doi.org/10.1016/j.ejsobi.2008.09.004

[65] Khan, A.L., Waqas, M., Kang, S.M., Al-Harrasi, A., Hussain, J., Al-Rawahi, A., et al. (2014) Bacterial Endophyte Sphingomonas sp. LK11 Produces Gibberellins and IAA and Promotes Tomato Plant Growth. Journal of Microbiology, 52, 689-695. https://doi.org/10.1007/s12275-014-4002-7

[66] Dias, A.C.F., Costa, F.E.C., Andreote, F.D., Lacava, P.T., Teixeira, M.A., Assumpção, L.C., et al. (2009) Isolation of Micropropagated Strawberry Endophytic Bacteria and Assessment of Their Potential for Plant Growth Promotion. World Journal of Microbiology and Biotechnology, 25, 189-195.

https://doi.org/10.1007/s11274-008-9878-0 


\section{Appendix}

Table S1. List of endophytic bacterial strains isolated from Nepalese sweet potato tubers.

\begin{tabular}{|c|c|c|c|c|c|}
\hline Locations & Strains & $\begin{array}{l}\text { Close relatives based on } 16 \mathrm{~S} \\
\text { rRNA gene sequencing }\end{array}$ & Class & a & b \\
\hline \multirow[t]{30}{*}{ Rolpa } & Rol 1 & Curtobacterium luteum & Actinobacteria & $x$ & $x$ \\
\hline & Rol 2 & Stenotrophomonas rhizophila & Gammaproteobacteria & $x$ & $x$ \\
\hline & Rol 3 & Brachybacterium rhamnosum & Actinobacteria & $x$ & $x$ \\
\hline & Rol 4 & Staphylococcus sciuri & Bacilli & $x$ & $x$ \\
\hline & Rol 5 & Yokenella regensburgei & Gammaproteobacteria & $x$ & $x$ \\
\hline & Rol 6 & Streptomyces viridochromogenes & Actinobacteria & $x$ & $x$ \\
\hline & Rol 7 & Massilia haematophila & Betaproteobacteria & $x$ & $x$ \\
\hline & Rol 8 & Enterobacter cloacae & Gammaproteobacteria & $x$ & \\
\hline & Rol 9 & Enterobacter asburiae & Gammaproteobacteria & & \\
\hline & Rol 10 & Curtobacterium luteum & Actinobacteria & & \\
\hline & Rol 11 & Curtobacterium luteum & Actinobacteria & & \\
\hline & Rol 12 & Curtobacterium luteum & Actinobacteria & & \\
\hline & Rol 13 & Flavobacterium johnsoniae & Flavobacteriia & & \\
\hline & Rol 14 & Yokenella regensburgei & Gammaproteobacteria & & \\
\hline & Rol 15 & Microbacterium paraoxydans & Actinobacteria & $x$ & \\
\hline & Rol 16 & Massilia haematophila & Betaproteobacteria & & \\
\hline & Rol 17 & Flavobacterium johnsoniae & Flavobacteriia & & \\
\hline & Rol 18 & Flavobacterium johnsoniae & Flavobacteriia & & \\
\hline & Rol 19 & Curtobacterium luteum & Actinobacteria & & \\
\hline & Rol 20 & Curtobacterium luteum & Actinobacteria & & \\
\hline & Rol 21 & Curtobacterium luteum & Actinobacteria & & \\
\hline & Rol 22 & Microbacterium paraoxydans & Actinobacteria & & \\
\hline & Rol 23 & Staphylococcus xylosus & Bacilli & & \\
\hline & Rol 24 & Staphylococcus saprophyticus & Bacilli & & \\
\hline & Rol 25 & Staphylococcus saprophyticus & Bacilli & & \\
\hline & Rol 26 & Staphylococcus saprophyticus & Bacilli & & \\
\hline & Rol 27 & Flavobacterium johnsoniae & Flavobacteriia & & \\
\hline & Rol 28 & Flavobacterium johnsoniae & Flavobacteriia & $x$ & \\
\hline & Rol 29 & Flavobacterium johnsoniae & Flavobacteriia & & \\
\hline & Rol 30 & Flavobacterium johnsoniae & Flavobacteriia & & \\
\hline \multirow[t]{4}{*}{ Salyan } & Sal 1 & Klebsiella variicola & Gammaproteobacteria & $x$ & $x$ \\
\hline & Sal 2 & Flavobacterium johnsoniae & Flavobacteriia & $x$ & $x$ \\
\hline & Sal 3 & Enterobacter asburiae & Gammaproteobacteria & $x$ & $x$ \\
\hline & Sal 4 & Rhizobium pusense & Alphaproteobacteria & $x$ & $x$ \\
\hline
\end{tabular}




\section{Continued}

\begin{tabular}{|c|c|c|c|c|}
\hline Sal 5 & Stenotrophomonas rhizophila & Gammaproteobacteria & $x$ & $x$ \\
\hline Sal 6 & Herbaspirillum huttiense & Betaproteobacteria & $x$ & $x$ \\
\hline Sal 7 & Agrobacterium larrymoorei & Alphaproteobacteria & $x$ & $x$ \\
\hline Sal 8 & Microbacterium testaceum & Actinobacteria & $x$ & $x$ \\
\hline Sal 9 & Stenotrophomonas rhizophila & Gammaproteobacteria & & \\
\hline Sal 10 & Flavobacterium johnsoniae & Flavobacteriia & & \\
\hline Sal 11 & Klebsiella variicola & Gammaproteobacteria & & \\
\hline Sal 12 & Rhizobium cellulosilyticum & Alphaproteobacteria & & \\
\hline Sal 13 & Bacillus megaterium & Bacilli & $x$ & \\
\hline Sal 14 & Flavobacterium anhuiense & Flavobacteriia & & \\
\hline Sal 15 & Stenotrophomonas rhizophila & Gammaproteobacteria & & \\
\hline Sal 16 & Klebsiella variicola & Gammaproteobacteria & & \\
\hline Sal 17 & Stenotrophomonas maltophilia & Gammaproteobacteria & & \\
\hline Sal 18 & Stenotrophomonas maltophilia & Gammaproteobacteria & & \\
\hline Sal 19 & Stenotrophomonas maltophilia & Gammaproteobacteria & & \\
\hline Sal 20 & Flavobacterium johnsoniae & Flavobacteriia & & \\
\hline Sal 21 & Stenotrophomonas rhizophila & Gammaproteobacteria & & \\
\hline Sal 22 & Stenotrophomonas rhizophila & Gammaproteobacteria & & \\
\hline Sal 23 & Flavobacterium johnsoniae & Flavobacteriia & & \\
\hline Sal 24 & Klebsiella variicola & Gammaproteobacteria & & \\
\hline Sal 25 & Microbacterium testaceum & Actinobacteria & & \\
\hline Sal 26 & Rhizobium pusense & Alphaproteobacteria & & \\
\hline Sal 27 & Herbaspirillum huttiense & Betaproteobacteria & & \\
\hline Sal 28 & Stenotrophomonas rhizophila & Gammaproteobacteria & & \\
\hline Sal 29 & Flavobacterium johnsoniae & Flavobacteriia & & \\
\hline Sal 30 & Klebsiella pneumoniae & Gammaproteobacteria & & \\
\hline Sal 31 & Klebsiella pneumoniae & Gammaproteobacteria & & \\
\hline Sal 32 & Klebsiella variicola & Gammaproteobacteria & & \\
\hline Sal 33 & Flavobacterium johnsoniae & Flavobacteriia & & \\
\hline Sal 34 & Flavobacterium anhuiense & Flavobacteriia & & \\
\hline Sal 35 & Stenotrophomonas rhizophila & Gammaproteobacteria & & \\
\hline Sal 36 & Herbaspirillum huttiense & Betaproteobacteria & & \\
\hline Sal 37 & Klebsiella pneumoniae & Gammaproteobacteria & & \\
\hline Sal 38 & Rhizobium pusense & Alphaproteobacteria & & \\
\hline Sal 39 & Stenotrophomonas maltophilia & Gammaproteobacteria & & \\
\hline Sal 40 & Stenotrophomonas rhizophila & Gammaproteobacteria & & \\
\hline Sal 41 & Flavobacterium johnsoniae & Flavobacteriia & & \\
\hline
\end{tabular}


Continued

\begin{tabular}{|c|c|c|c|c|c|}
\hline & Sal 42 & Flavobacterium johnsoniae & Flavobacteriia & & \\
\hline & Sal 43 & Flavobacterium johnsoniae & Flavobacteriia & & \\
\hline \multirow[t]{2}{*}{ Gulmi } & Gul 1 & Bacillus pumilus & Bacilli & $x$ & $x$ \\
\hline & Gul 2 & Bacillus safensis & Bacilli & & \\
\hline \multirow[t]{6}{*}{ Palpa } & Pal 1 & Rhizobium cellulosilyticum & Alphaproteobacteria & $x$ & \\
\hline & $\mathrm{Pal} 2$ & Enterobacter cloacae & Gammaproteobacteria & & \\
\hline & Pal 3 & Luteibacter yeojuensis & Gammaproteobacteria & $x$ & \\
\hline & $\mathrm{Pal} 4$ & Enterobacter cloacae & Gammaproteobacteria & $x$ & \\
\hline & Pal 5 & Bacillus wiedmannii & Bacilli & $x$ & \\
\hline & Pal 6 & Bacillus thuringiensis & Bacilli & & \\
\hline \multirow[t]{5}{*}{ Kavre-a } & Kav-a 1 & Herbaspirillum seropedicae & Betaproteobacteria & $x$ & $x$ \\
\hline & Kav-a 2 & Pseudomonas oryzihabitans & Gammaproteobacteria & $x$ & $x$ \\
\hline & Kav-a 3 & Agrobacterium tumefaciens & Alphaproteobacteria & $x$ & \\
\hline & Kav-a 4 & Agrobacterium fabrum & Alphaproteobacteria & & \\
\hline & Kav-a 5 & Bacillus wiedmannii & Bacilli & $x$ & \\
\hline \multirow[t]{17}{*}{ Kavre-b } & Kav-b 1 & Caballeronia temeraria & Betaproteobacteria & $x$ & $x$ \\
\hline & Kav-b 2 & Staphylococcus succinus & Bacilli & $x$ & $x$ \\
\hline & Kav-b 3 & Luteibacter yeojuensis & Gammaproteobacteria & $x$ & $x$ \\
\hline & Kav-b 4 & Rhizobium miluonense & Alphaproteobacteria & $x$ & $x$ \\
\hline & Kav-b 5 & Bacillus cereus & Bacilli & $x$ & $x$ \\
\hline & Kav-b 6 & Caballeronia temeraria & Betaproteobacteria & & \\
\hline & Kav-b 7 & Herbaspirillum huttiense & Betaproteobacteria & $x$ & \\
\hline & Kav-b 8 & Staphylococcus saprophyticus & Bacilli & & \\
\hline & Kav-b 9 & Rhizobium pusense & Alphaproteobacteria & & \\
\hline & Kav-b 10 & Achromobacter xylosoxidans & Betaproteobacteria & $x$ & \\
\hline & Kav-b 11 & Pantoea stewartii & Gammaproteobacteria & $x$ & \\
\hline & Kav-b 12 & Achromobacter xylosoxidans & Betaproteobacteria & & \\
\hline & Kav-b 13 & Bacillus cereus & Bacilli & & \\
\hline & Kav-b 14 & Bacillus cereus & Bacilli & & \\
\hline & Kav-b 15 & Bacillus cereus & Bacilli & & \\
\hline & Kav-b 16 & Bacillus wiedmannii & Bacilli & & \\
\hline & Kav-b 17 & Bacillus cereus & Bacilli & & \\
\hline \multirow{5}{*}{ Banke-a } & Ban-a 1 & Microbacterium radiodurans & Actinobacteria & $x$ & $x$ \\
\hline & Ban-a 2 & Curtobacterium citreum & Actinobacteria & $x$ & $x$ \\
\hline & Ban-a 3 & Agrobacterium larrymoorei & Alphaproteobacteria & $x$ & $x$ \\
\hline & Ban-a 4 & Rhizobium cellulosilyticum & Alphaproteobacteria & $x$ & $x$ \\
\hline & Ban-a 5 & Arthrobacter pokkalii & Actinobacteria & $x$ & $x$ \\
\hline
\end{tabular}




\section{Continued}

\begin{tabular}{|c|c|c|c|c|c|}
\hline & Ban-a 6 & Cellulomonas hominis & Actinobacteria & $x$ & $\times$ \\
\hline & Ban-a 7 & Pantoea stewartii & Gammaproteobacteria & $x$ & $x$ \\
\hline & Ban-a 8 & Microbacterium radiodurans & Actinobacteria & $x$ & $x$ \\
\hline & Ban-a 9 & Sphingomonas yantingensis & Alphaproteobacteria & $x$ & $x$ \\
\hline & Ban-a 10 & Enterobacter cloacae & Gammaproteobacteria & $x$ & \\
\hline & Ban-a 11 & Curtobacterium citreum & Actinobacteria & & \\
\hline & Ban-a 12 & Curtobacterium citreum & Actinobacteria & & \\
\hline & Ban-a 13 & Staphylococcus gallinarum & Bacilli & $x$ & \\
\hline & Ban-a 14 & Sphingomonas koreensis & Alphaproteobacteria & & \\
\hline & Ban-a 15 & Flavobacterium johnsoniae & Flavobacteriia & $x$ & \\
\hline & Ban-a 16 & Microbacterium radiodurans & Actinobacteria & & \\
\hline & Ban-a 17 & Microbacterium radiodurans & Actinobacteria & & \\
\hline & Ban-a 18 & Microbacterium oleivorans & Actinobacteria & & \\
\hline & Ban-a 19 & Microbacterium oleivorans & Actinobacteria & & \\
\hline & Ban-a 20 & Rhizobium cellulosilyticum & Alphaproteobacteria & & \\
\hline & Ban-a 21 & Arthrobacter enclensis & Actinobacteria & & \\
\hline & Ban-a 22 & Microbacterium radiodurans & Actinobacteria & & \\
\hline & Ban-a 23 & Microbacterium radiodurans & Actinobacteria & & \\
\hline & Ban-a 24 & Microbacterium radiodurans & Actinobacteria & & \\
\hline & Ban-a 25 & Sphingomonas yantingensis & Alphaproteobacteria & & \\
\hline & Ban-a 26 & Agrobacterium larrymoorei & Alphaproteobacteria & & \\
\hline & Ban-a 27 & Sphingomonas yantingensis & Alphaproteobacteria & & \\
\hline & Ban-a 28 & Microbacterium paraoxydans & Actinobacteria & & \\
\hline & Ban-a 29 & Microbacterium oleivorans & Actinobacteria & & \\
\hline & Ban-a 30 & Microbacterium oxydans & Actinobacteria & & \\
\hline & Ban-a 31 & Microbacterium oleivorans & Actinobacteria & & \\
\hline Banke-b & Ban-b 1 & Xenophilus aerolatus & Betaproteobacteria & $x$ & $\times$ \\
\hline & Ban-b 2 & Stenotrophomonas maltophilia & Gammaproteobacteria & $x$ & $\times$ \\
\hline & Ban-b 3 & Xanthomonas campestris & Gammaproteobacteria & $x$ & $x$ \\
\hline & Ban-b 4 & Sphingobium yanoikuyae & Alphaproteobacteria & $x$ & $x$ \\
\hline & Ban-b 5 & Microbacterium lemovicicum & Actinobacteria & $\times$ & $x$ \\
\hline & Ban-b 6 & Pseudoxanthomonas spadix & Gammaproteobacteria & $x$ & $x$ \\
\hline & Ban-b 7 & Xanthomonas translucens & Gammaproteobacteria & $x$ & $x$ \\
\hline & Ban-b 8 & Rhizobium pusense & Alphaproteobacteria & $x$ & \\
\hline & Ban-b 9 & Curtobacterium luteum & Actinobacteria & $x$ & \\
\hline & Ban-b 10 & Stenotrophomonas maltophilia & Gammaproteobacteria & & \\
\hline & Ban-b 11 & Rhizobium giardinii & Alphaproteobacteria & & \\
\hline
\end{tabular}




\section{Continued}

\begin{tabular}{|c|c|c|c|c|c|}
\hline & Ban-b 12 & Rhizobium pusense & Alphaproteobacteria & & \\
\hline & Ban-b 13 & Xanthomonas campestris & Gammaproteobacteria & & \\
\hline & Ban-b 14 & Agrobacterium fabrum & Alphaproteobacteria & & \\
\hline & Ban-b 15 & Agrobacterium larrymoorei & Alphaproteobacteria & & \\
\hline & Ban-b 16 & Stenotrophomonas panacihumi & Gammaproteobacteria & & \\
\hline & Ban-b 17 & Sphingobium yanoikuyae & Alphaproteobacteria & & \\
\hline & Ban-b 18 & Curtobacterium citreum strain & Actinobacteria & & \\
\hline & Ban-b 19 & Rhizobium cellulosilyticum & Alphaproteobacteria & & \\
\hline & Ban-b 20 & Xenophilus aerolatus & Betaproteobacteria & & \\
\hline & Ban-b 21 & Sphingobium yanoikuyae & Alphaproteobacteria & & \\
\hline & Ban-b 22 & Sphingobium yanoikuyae & Alphaproteobacteria & & \\
\hline & Ban-b 23 & Curtobacterium luteum & Actinobacteria & & \\
\hline & Ban-b 24 & Agrobacterium tumefaciens & Alphaproteobacteria & & \\
\hline & Ban-b 25 & Rhizobium pusense & Alphaproteobacteria & & \\
\hline & Ban-b 26 & Stenotrophomonas maltophilia & Gammaproteobacteria & & \\
\hline & Ban-b 27 & Pseudoxanthomonas spadix & Gammaproteobacteria & $x$ & \\
\hline & Ban-b 28 & Xanthomonas translucens & Gammaproteobacteria & & \\
\hline & Ban-b 29 & Agrobacterium larrymoorei & Alphaproteobacteria & $x$ & \\
\hline & Ban-b 30 & Rhizobium pusense & Alphaproteobacteria & & \\
\hline & Ban-b 31 & Xanthomonas translucens & Gammaproteobacteria & & \\
\hline & Ban-b 32 & Xenophilus aerolatus & Betaproteobacteria & & \\
\hline Rupandehi & Rup 1 & Microbacterium binotii & Actinobacteria & $x$ & $x$ \\
\hline & Rup 2 & Microbacterium arborescens & Actinobacteria & $x$ & $x$ \\
\hline & Rup 3 & Microbacterium hydrothermale & Actinobacteria & $x$ & $x$ \\
\hline & Rup 4 & Achromobacter xylosoxidans & Betaproteobacteria & $x$ & $x$ \\
\hline & Rup 5 & Curtobacterium citreum & Actinobacteria & $x$ & $x$ \\
\hline & Rup 6 & Microbacterium oleivorans & Actinobacteria & $x$ & $x$ \\
\hline & Rup 7 & Glutamicibacter nicotianae & Actinobacteria & $x$ & $x$ \\
\hline & Rup 8 & Microbacterium phyllosphaerae & Actinobacteria & $x$ & $x$ \\
\hline & Rup 9 & Rhizobium vallis & Alphaproteobacteria & $x$ & $x$ \\
\hline & Rup 10 & Paenibacillus taichungensis & Bacilli & $x$ & $x$ \\
\hline & Rup 11 & Microbacterium paraoxydans & Actinobacteria & $x$ & $x$ \\
\hline & Rup 12 & Exiguobacterium indicum & Bacilli & $x$ & $x$ \\
\hline & Rup 13 & Glutamicibacter nicotianae & Actinobacteria & $x$ & $x$ \\
\hline & Rup 14 & Curtobacterium luteum & Actinobacteria & & \\
\hline & Rup 15 & Glutamicibacter nicotianae & Actinobacteria & & \\
\hline & Rup 16 & Curtobacterium citreum & Actinobacteria & & \\
\hline
\end{tabular}




\section{Continued}

\begin{tabular}{|c|c|c|c|c|c|}
\hline & Rup 17 & Pseudarthrobacter niigatensis & Actinobacteria & & \\
\hline & Rup 18 & Rhizobium pusense & Alphaproteobacteria & & \\
\hline & Rup 19 & Achromobacter xylosoxidans & Betaproteobacteria & & \\
\hline & Rup 20 & Pseudarthrobacter niigatensis & Actinobacteria & $x$ & \\
\hline & Rup 21 & Achromobacter xylosoxidans & Betaproteobacteria & & \\
\hline & Rup 22 & Bacillus aryabhattai & Bacilli & $x$ & \\
\hline & Rup 23 & Pantoea dispersa & Gammaproteobacteria & $x$ & \\
\hline & Rup 24 & Pantoea dispersa & Gammaproteobacteria & & \\
\hline & Rup 25 & Glutamicibacter nicotianae & Actinobacteria & & \\
\hline & Rup 26 & Glutamicibacter nicotianae & Actinobacteria & & \\
\hline & Rup 27 & Curtobacterium luteum & Actinobacteria & & \\
\hline & Rup 28 & Microbacterium paraoxydans & Actinobacteria & & \\
\hline & Rup 29 & $\begin{array}{l}\text { Microbacterium hydrocarbonox- } \\
\text { ydans }\end{array}$ & Actinobacteria & & \\
\hline & Rup 30 & $\begin{array}{l}\text { Microbacterium hydrocarbonox- } \\
\text { ydans }\end{array}$ & Actinobacteria & & \\
\hline & Rup 31 & Arthrobacter nicotianae & Actinobacteria & & \\
\hline & Rup 32 & Arthrobacter nicotianae & Actinobacteria & & \\
\hline & Rup 33 & Arthrobacter nicotianae & Actinobacteria & & \\
\hline & Rup 34 & $\begin{array}{l}\text { Microbacterium hydrocarbonox- } \\
\text { ydans }\end{array}$ & Actinobacteria & & \\
\hline & Rup 35 & Achromobacter xylosoxidans & Betaproteobacteria & & \\
\hline & Rup 36 & Achromobacter xylosoxidans & Betaproteobacteria & & \\
\hline & Rup 37 & Achromobacter xylosoxidans & Betaproteobacteria & & \\
\hline Chitwan & Chi 1 & Pantoea dispersa & Gammaproteobacteria & $x$ & $x$ \\
\hline & Chi 2 & Paraburkholderia caribensis & Betaproteobacteria & $x$ & $x$ \\
\hline & Chi 3 & Neorhizobium alkalisoli & Alphaproteobacteria & $x$ & $x$ \\
\hline & Chi 4 & Bacillus megaterium & Bacilli & $x$ & \\
\hline & Chi 5 & Bacillus aryabhattai & Bacilli & & \\
\hline & Chi 6 & Stenotrophomonas maltophilia & Gammaproteobacteria & $x$ & \\
\hline & Chi 7 & Enterobacter cloacae & Gammaproteobacteria & $x$ & \\
\hline & Chi 8 & Burkholderia vietnamiensis & Betaproteobacteria & & \\
\hline & Chi 9 & Bacillus safensis & Bacilli & & \\
\hline & Chi 10 & Burkholderia caribensis & Betaproteobacteria & & \\
\hline & Chi 11 & Bacillus pumilus & Bacilli & & \\
\hline & Chi 12 & Bacillus safensis & Bacilli & & \\
\hline & Chi 13 & Bacillus safensis & Bacilli & & \\
\hline & Chi 14 & Bacillus safensis & Bacilli & & \\
\hline
\end{tabular}




\section{Continued}

\begin{tabular}{|c|c|c|c|c|c|}
\hline \multirow[t]{18}{*}{ Sunsari-a } & Sun-a 1 & Pseudomonas nitroreducens & Gammaproteobacteria & $x$ & $x$ \\
\hline & Sun-a 2 & Pseudomonas nitroreducens & Gammaproteobacteria & $x$ & $x$ \\
\hline & Sun-a 3 & Bacillus megaterium & Bacilli & $x$ & $x$ \\
\hline & Sun-a 4 & Pseudomonas nitroreducens & Gammaproteobacteria & $x$ & $x$ \\
\hline & Sun-a 5 & Pseudomonas nitroreducens & Gammaproteobacteria & & \\
\hline & Sun-a 6 & Enterobacter asburiae & Gammaproteobacteria & $x$ & \\
\hline & Sun-a 7 & Pseudomonas aeruginosa & Gammaproteobacteria & & \\
\hline & Sun-a 8 & Enterobacter cloacae & Gammaproteobacteria & & \\
\hline & Sun-a 9 & Bacillus safensis & Bacilli & & \\
\hline & Sun-a 10 & Rhizobium etli & Alphaproteobacteria & $x$ & \\
\hline & Sun-a 11 & Bacillus megaterium & Bacilli & & \\
\hline & Sun-a 12 & Pseudomonas nitritireducens & Gammaproteobacteria & & \\
\hline & Sun-a 13 & Pseudomonas nitroreducens & Gammaproteobacteria & & \\
\hline & Sun-a 14 & Bacillus megaterium & Bacilli & & \\
\hline & Sun-a 15 & Bacillus megaterium & Bacilli & & \\
\hline & Sun-a 16 & Bacillus megaterium & Bacilli & & \\
\hline & Sun-a 17 & Bacillus megaterium & Bacilli & & \\
\hline & Sun-a 18 & Bacillus megaterium & Bacilli & & \\
\hline \multirow[t]{8}{*}{ Sunsari-b } & Sun-b 1 & Burkholderia cenocepacia & Betaproteobacteria & $x$ & $x$ \\
\hline & Sun-b 2 & Burkholderia cepacia & Betaproteobacteria & & \\
\hline & Sun-b 3 & Burkholderia ambifaria & Betaproteobacteria & & \\
\hline & Sun-b 4 & Burkholderia cenocepacia & Betaproteobacteria & & \\
\hline & Sun-b 5 & Burkholderia cenocepacia & Betaproteobacteria & & \\
\hline & Sun-b 6 & Bacillus safensis & Bacilli & & \\
\hline & Sun-b 7 & Burkholderia cepacia & Betaproteobacteria & & \\
\hline & Sun-b 8 & Burkholderia territorii & Betaproteobacteria & & \\
\hline
\end{tabular}

a: Strains used for the inoculation experiment, b: Strains selected for characterizing their plant growth promoting and endophytic traits. 


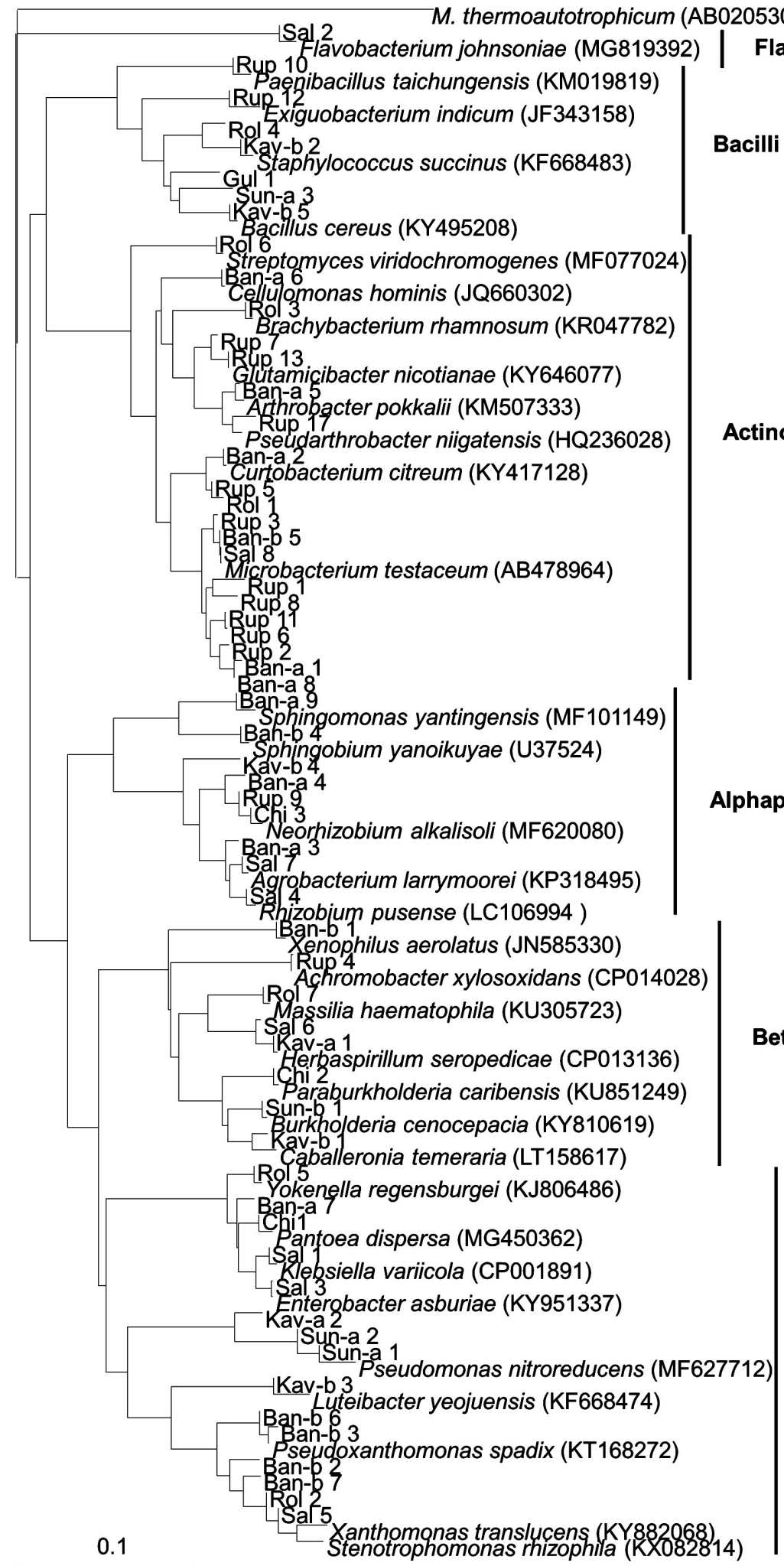

Betaproteobacteria

Gammaproteobacteria

Figure S1. Phylogenetic relationship of 60 selected endophytic bacterial strains from Nepalese sweet potato based on partial 16S rRNA gene sequences. The sequence of Methanobacterium thermoautotrophicum (AB020530) served as an outgroup. Strain names are listed in Table S1. Strain names followed by accession numbers represent the sequences from database. The scale bar indicates the number of substitutions per site. 